\title{
Input Parameters for the Simulation of Silicon Solar Cells in 2014
}

\author{
Andreas Fell, Keith R. McIntosh, Pietro P. Altermatt, Gaby J. M. Janssen, Rolf Stangl, Anita Ho-Baillie, \\ Heiko Steinkemper, Johannes Greulich, Matthias Müller, Byungsul Min, Kean C. Fong, Martin Hermle, \\ Ingrid G. Romijn, and Malcolm D. Abbott
}

(Review Paper)

\begin{abstract}
Within the silicon photovoltaics (PV) community, there are many approaches, tools, and input parameters for simulating solar cells, making it difficult for newcomers to establish a complete and representative starting point and imposing high requirements on experts to tediously state all assumptions and inputs for replication. In this review, we address these problems by providing complete and representative input parameter sets to simulate six major types of crystalline silicon solar cells. Where possible, the inputs are justified and up-to-date for the respective cell types, and they produce representative measurable cell characteristics. Details of the modeling approaches that can replicate the simulations are presented as well. The input parameters listed here provide a sensible and consistent reference point for researchers on which to base their refinements and extensions.
\end{abstract}

Index Terms-Photovoltaic (PV) cells, semiconductor device modeling, silicon solar cells, solar cell simulation.

\section{INTRODUCTION}

D EVICE simulation helps photovoltaics (PV) researchers to understand solar cells, to perform loss analyses, to

Manuscript received February 5, 2015; accepted April 28, 2015. Date of publication May 25, 2015; date of current version June 18, 2015. The work of A. Fell was supported by the Australian Renewable Energy Agency under the postdoctoral fellowship project 5-F007.

A. Fell and K. C. Fong are with the College of Engineering and Computer Science, The Australian National University, Canberra, A.C.T. 2601, Australia (e-mail: andreas.fell@anu.edu.au; kean.fong @anu.edu.au).

K. R. McIntosh and M. D. Abbott are with PV Lighthouse, Coledale, N.S.W. 2515, Australia (e-mail: krmcintosh@pvlighthouse.com.au; mal abbott@pvlighthouse.com.au).

P. P. Altermatt is with the Institute of Solid State Physics, Leibniz University of Hannover, Hannover, 30167, Germany, and also with the Institute of Solar Energy Research, Hamelin 31860, Germany (e-mail: altermatt@solar uni-hannover.de).

G. J. M. Janssen and I. G. Romijn are with the Energy Research Center of the Netherlands, 1755LE Petten, The Netherlands (e-mail: janssen@ecn.nl; romijn@ecn.nl).

R. Stangl is with the Solar Energy Research Institute of Singapore, 117574 Singapore (e-mail: rolf.stangl@nus.edu.sg).

A. Ho-Baillie is with the School of Photovoltaic and Renewable Energy Engineering, University of New South Wales, Sydney, N.S.W. 2052, Australia (e-mail: a.ho-baillie@unsw.edu.au).

H. Steinkemper, J. Greulich, and M. Hermle are with the Fraunhofer Institute for Solar Energy Systems, Freiburg 79110, Germany (e-mail: heiko. steinkemper@ise.fraunhofer.de; johannes.greulich@ise.fraunhofer.de; martin. hermle@ise.fraunhofer.de).

M. Müller is with SolarWorld Innovations GmbH, Freiberg 09599, Germany (e-mail: matthias.mueller@solarworld-innovations.de).

B. Min is with the Institute of Solar Energy Research, Hamelin 31860 , Germany (e-mail: min@isfh.de).

Color versions of one or more of the figures in this paper are available online at http://ieeexplore.ieee.org.

Digital Object Identifier 10.1109/JPHOTOV.2015.2430016 predict how changes to a solar cell design or fabrication procedure will affect its efficiency, and to provide a quantitative foundation to decide on R\&D strategies. In their timeless quest to increase accuracy (and reduce complexity), researchers have generated a plethora of equations, algorithms, parameterizations, and programs to simulate solar cells. To the newcomer, the vast array of approaches and possible inputs can be confounding. To the old timer, it is tedious to state all of the inputs and assumptions that ensure a fellow researcher can replicate and test their simulations.

We seek to alleviate these problems by providing a set of inputs to simulate six major types of silicon solar cells. The input sets comprise a starting point for new comers and provide a reference point from which researchers can base their refinements and extensions. The input sets contain the physical properties of the cells, and as such, they are not specific to any modeling approach or software tool.

In addition to providing parameter sets, we apply a specific modeling approach and set of software tools to simulate the optical and electrical behavior of the solar cells. It presents a balance between a high level of detail to cover detrimental physical effects and a low level of complexity to be reproducible and comprehensible to nonexperts. Notably, a subset of the used software tools is freely available, providing a readily accessible way to reproduce the presented results.

The first two parameter sets represent industrial screenprinted solar cells. Due to issues of commercial confidentiality, compromises are made in the selection of values to make public here. Most notably, the inputs that define the emitter profiles and metallization are more representative of recent forerunners to modern industrial cells, rather than those produced in 2014 . Nevertheless, the datasets provide a complete and sensible starting point from which readers can critically examine, debate, and substitute inputs. No such compromises are made in the remaining four parameter sets, which represent laboratory-based solar cells whose structures and behavior have been published in detail. A preliminary version of the first parameter set was published in [1].

For completeness, the text that follows is replete with assumptions and qualifiers, many of which require a background in solar cell physics to comprehend. The new comer need not be discouraged by this level of detail. They can commence by downloading the parameter sets from an online solar cell library [2], varying the inputs in the appropriate software and 


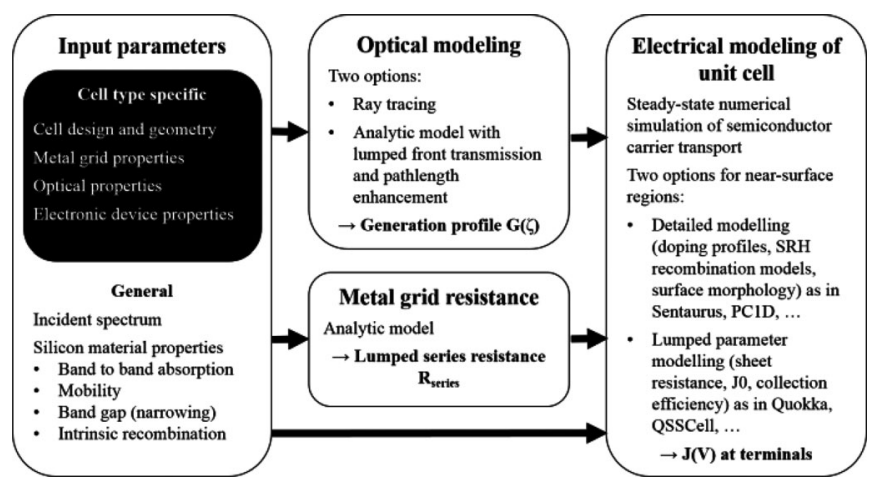

Fig. 1. Flowchart describing the modeling approach; highlighted are the celltype specific input parameters which form the scope of this work.

observing how the efficiency of a particular cell type depends on its physical structure.

\section{Modeling APPROACH}

The modeling approach followed in this work is sketched in Fig. 1. It can be divided into optical modeling to derive the generation profile, calculation of a lumped series resistance to represent the metal grid resistive losses, and electrical simulation of an element of symmetry (a unit cell). For the sake of keeping complexity at a moderate level, this approach neglects some full-size effects: perimeter losses, busbar recombination, the distributed nature of the metal grid resistance, and inhomogeneity of the silicon wafer. Details of the assumptions and simplifications are stated in the following sections.

\section{A. Optical Modeling}

The purpose of the optical modeling is to determine the generation profile of electron-hole pairs within the silicon. This requires knowledge of the incident illumination, the surface morphologies, the thickness of the wafer and any films, and the complex refractive index of all materials.

Parameter sets for two modeling approaches are presented. Importantly, both approaches modify the generation profile under textured surfaces such that it approximates the profile under an equivalent planar surface. It greatly simplifies the subsequent electrical modeling to treat the solar cell as having planar surfaces.

The first approach is ray tracing, here performed with Sentaurus Device [3] or the Wafer ray tracer on PV Lighthouse [4]. Both are able to directly compute the generation profile $G(\zeta)$ of electron-hole pairs in the silicon, where $\zeta$ is defined as the shortest distance to the illuminated surface [5]. The purpose of using $\zeta$ rather than depth is that it converts the generation profile under a complicated geometry (e.g., random pyramids) to an equivalent generation profile under a planar surface.

The second approach to the optical modeling is to use the front-surface transmission $T_{\text {ext }}(\lambda)$ and the pathlength enhancement $Z(\lambda)$ as inputs, which are both a function of wavelength $\lambda$. As described in detail in [6], those quantities are used to calculate the generation profile by an analytical model similar to the one presented in [7] and are suitable inputs, e.g., for the solar cell simulator Quokka [8]. Furthermore, the related reflection, absorption, and transmission data are used for comparison to quantum efficiency (QE) measurements of finished solar cells, with the purpose of validating and calibrating the optical and electrical input parameters.

Shading by fingers is represented by nil generation underneath their effective shading width, whereas busbar shading is considered by either a global scaling of the generation profile or a postsimulation scaling of the current density, which gives almost identical results. The influence of altered internal reflectivity at finger and busbar regions is neglected for simplicity. Furthermore, free-carrier absorption and photon reabsorption are neglected or effectively incorporated into rear reflector assumptions to fit measured $J_{\mathrm{sc}}$.

\section{B. Metal Grid Resistance}

The metal grid resistance is represented by a lumped series resistance value $R_{\text {series }}$, thereby neglecting the influence of its distributed nature. This can overestimate the fill factor (FF) for cells that have a significant metal resistance, but for the cells presented here, it was concluded from SPICE modeling that the assumption has minimal influence on FF. $R_{\text {series }}$ is derived by analytical modeling, as described in [9], using Grid on PV Lighthouse. Contact resistance is excluded from the lumped series resistance because it is included in the electrical modeling, thereby accounting for related current transfer effects. Busbar resistance is neglected, which is consistent with a high number of measurement probes along the busbar during current-voltage testing. Unless stated otherwise, a rectangular profile of metal fingers is assumed.

\section{Electrical Modeling of the Unit Cell}

To derive the current-voltage $(I-V)$ and QE characteristics of the solar cell, electrical modeling of the unit cell is performed by means of steady-state numerical simulation of the semiconductor carrier transport in two or three dimensions. There are essentially two different ways of treating near-surface regions: 1) lumped parameter modeling (i.e., the conductive boundary approach) and 2) detailed modeling.

The first approach has the advantage of being simpler and much faster. The near-surface region is treated as a boundary condition, described by a set of lumped input parameters consisting of the sheet resistance $R_{\text {sheet }}$, the collection efficiency $\eta_{\mathrm{c}}$, and a (injection-dependent) recombination parameter $J_{0}$ or

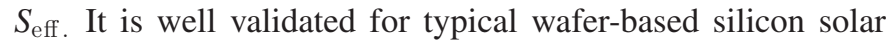
cells and implemented in several software tools, e.g., in Quokka [8], [10], CoBoGUI [11], PC2D [12], and QSSCell [13], [14].

The second approach is more computationally expensive, but it includes the physical nature of the surfaces and immediate subsurface regions. It simulates them by solving a set of bestknown physical models that describe the electrical, optical, and thermal properties of the material system. The main inputs for solar devices are the doping profile $N(\zeta)$, the surface ShockleyRead-Hall (SRH) recombination parameters $S_{\mathrm{n}}$ and $S_{\mathrm{p}}$, the surface charge $Q$, and at times empirical correction factors in case of a textured surface morphology. This approach provides more insight into the detailed operation of the device and must be used when effects within the near-surface regions are investigated. It 
is well established and implemented in several software tools, e.g., in Sentaurus Device [3], Atlas [15], EDNA [16], in the Semiconductor Module of Comsol Multiphysics [17], [18] and PC1D [19], [20].

As described in Section II-A, a textured surface is approximated by a planar electrical solution domain, which for the detailed modeling necessitates the introduction of correction factors to reproduce experimentally measured characteristics. Most importantly, the recombination increases due to surface area enlargement, which is addressed by increasing recombination parameters, mainly $S_{\mathrm{n} 0}$ and $S_{\mathrm{p} 0}$, and optionally volumetric Auger and SRH recombination by a texture multiplier (typically $1.3-1.7$ ). While the measured $J_{0}$ can be reproduced by this approach, an accurate representation of the collection efficiency $\eta_{c}$ (ratio of collected and generated carriers within the near-surface region) is difficult to achieve simultaneously. The conductive boundary approach avoids this problem by setting $J_{0}, R_{\text {sheet }}$, and $\eta_{\mathrm{c}}$ independently of one another to empirically determined values. Due to zero generation underneath fingers, $\eta_{\mathrm{c}}$ for contacted regions is irrelevant and consequently not given in the input parameter sets.

It is also possible to use a combined approach in which aspects of the cell that cannot be directly measured are first simulated with detailed modeling, and then, the lumped outputs are used in a subsequent conductive boundary model.

In this paper, we describe how each solar cell structure can be consistently simulated with both the lumped parameter and detailed approach. For lumped parameter modeling, we use a combination of EDNA [16] to perform detailed surface modeling (where lumped parameters are not directly available) and Quokka [8] for conductive boundary device simulations. Complete detailed modeling is performed with the commercial device simulation software Sentaurus Device [3] or Atlas [15].

In this work, the simulation of the electrical performance of the unit cell neglects some of the specific regions of a real solar cell. Most notable is the impact of the busbar and edge regions. In addition, some solar cells also have solder contact pads that can introduce additional recombination due to the lack of BSF formed. In all of the front-contact simulations presented here (except the PERL cell which has no busbar), the impact of the busbar shading is considered as described in the Section II-A. For simplicity, the recombination impact of these regions is neglected as is any impact from the edge regions. Furthermore, any $J_{02}$ and $R_{\text {shunt }}$ contributions from edges and busbars are neglected, again for simplicity.

\section{INPUT PARAMETER SETS}

The main purpose of this work is to present complete and representative parameter sets for six major silicon solar cell structures. The first two sets are for common commercial solar cells, and the other four sets are laboratory-based solar cells. The input parameters comprise a mixture of measured, modeled, and empirically fitted values, as stated for the individual cell types.

We emphasize that the input parameters cannot provide a precise description of every solar cell of a given structure. The PV industry manufactures cells with a wide distribution of $I-V$ performance, largely due to a wide distribution in the quality
TABLE I

GENERAL INPUT PARAMETERS USED IN THIS WORK

\begin{tabular}{|c|c|}
\hline Temperature & $298.15 \mathrm{~K}\left(25^{\circ} \mathrm{C}\right)$ \\
\hline free carrier statistics & $\begin{array}{l}\text { Fermi-Dirac for highly doped regions Boltzmann } \\
\text { for bulk (equals Fermi-Dirac for low doping) }\end{array}$ \\
\hline intrinsic carrier density & $\begin{array}{l}8.27 \times 10^{9} \mathrm{~cm}^{-3} \text { (calculated from [eq. (3), 23] } \\
\text { multiplied by } 0.9953 \text { to match } 9.65 \times 10^{9} \mathrm{~cm}^{-3} \text { at } \\
300 \mathrm{~K}[24])\end{array}$ \\
\hline bandgap narrowing & $\begin{array}{l}\text { no BGN for bulk in conductive boundary } \\
\text { modeling, Schenk [25] otherwise }\end{array}$ \\
\hline Auger recombination & Richter et al. [26] $(300 \mathrm{~K})$ \\
\hline radiative recombination & $B_{\mathrm{rad}}=4.73 \times 10^{-15} \mathrm{~cm}^{3} / \mathrm{s}[27](300 \mathrm{~K})$ \\
\hline mobility & Klaassen [28] \\
\hline incident spectrum & AM1.5g [29] \\
\hline optical properties $\mathrm{Si}$ & Green [30] \\
\hline
\end{tabular}

of silicon wafers but due to ongoing improvements in materials, equipment and processes and to temporal variability in production lines as well.

The parameter sets provided for the industry-typical cells (A, B) are necessarily nebulous. They are not generated from any specific solar cell, but are selected to represent a "typical" cell within the wide variety manufactured in industry. The parameter sets do not represent the "state-of-the-art" in 2014, and they will be outdated in the near future. In fact, some inputs could already be considered outdated, a necessary consequence of commercial confidentiality. To supplement the specific values, we therefore provide a value range for those inputs that are well known to have a wide distribution.

The parameter sets for the laboratory-based cells $(\mathrm{C}-\mathrm{F})$ are more specific because, with the exception of the heterojunction technology (HJT) cell (D), they have been determined from measurements on a particular experimental solar cell. The inputs for the HJT cell combine properties from different laboratories (not industry). Thus, the laboratory-based cells are very specific to the technology applied by the respective institute and are also not representative of their equivalent industrial solar cells.

Thus, irrespective of the dataset, the reader is encouraged to use these inputs as a sensible and consistent starting point and to substitute their own values where appropriate.

\section{General Input Parameters}

An essential part of the input parameters form the general inputs common to all cell types, including the choice of parameterizations for modeling silicon properties. Table I summarizes the inputs used in this work, mostly as suggested in [21]. Notably, for Auger and radiative recombination, model parameters are valid at $300 \mathrm{~K}$ only. However, neglecting their temperature dependence results in minor effect on the simulation result compared with the large effect of the different intrinsic carrier concentration. We accept these inconsistencies and choose $25{ }^{\circ} \mathrm{C}(298.15 \mathrm{~K})$ to be more representative for standard testing conditions.

An important parameter for the conductive boundary modeling using $J_{0}$ values is the effective intrinsic carrier density $n_{\text {ieff }}$. We use the value of $n_{\text {ieff }}=n_{\mathrm{i}}=8.27 \times 10^{9} \mathrm{~cm}^{-3}$ (see Table I) in the bulk consistently throughout this work for conductive boundary modeling, neglecting the small amount of bandgap 
TABLE II

InPut Parameter Set for the Conventional Cell

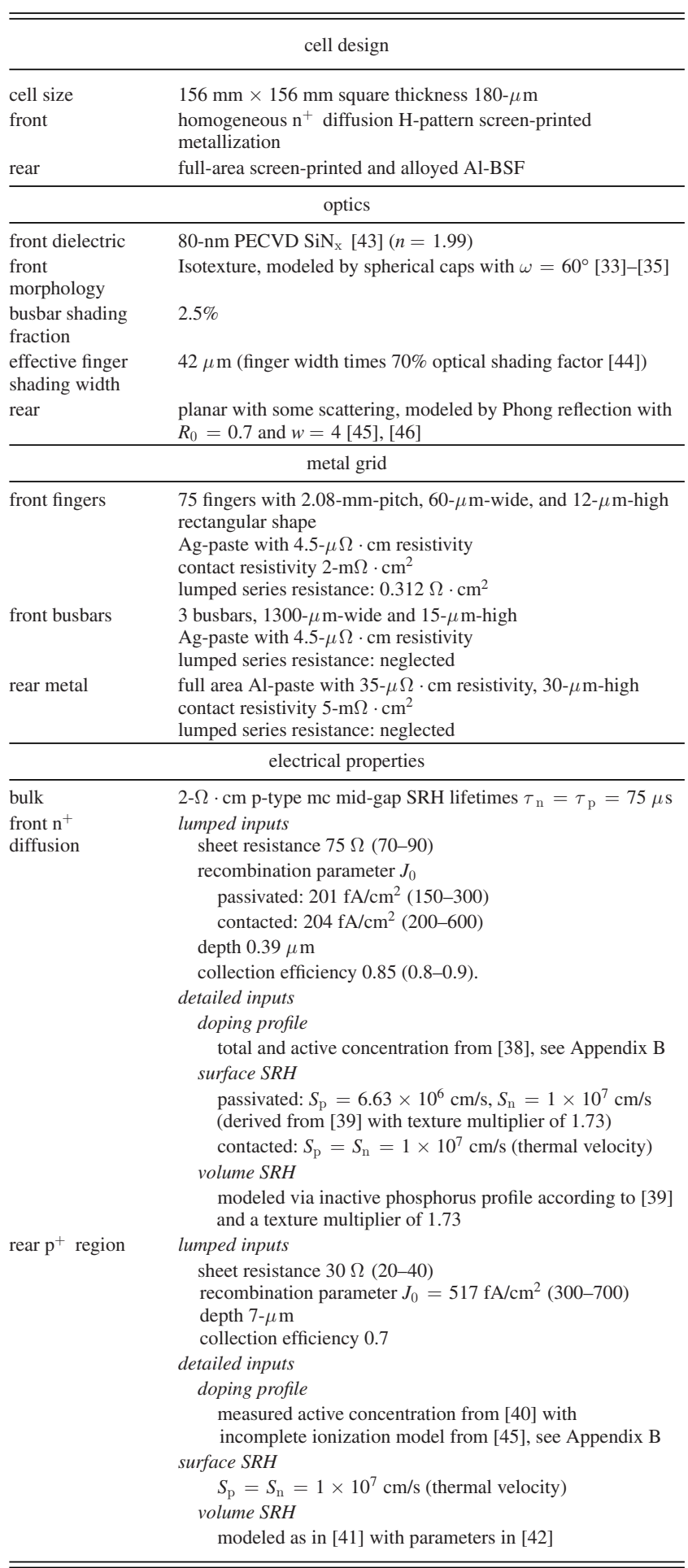

narrowing. $J_{0}$ values derived with a different assumption of $n_{\text {ieff }}$ are scaled according to $J_{0} / n_{\text {ieff }}{ }^{2}=$ const [22].

\section{A. Conventional (Industry Typical Properties): p-Type Full-Area Rear-Alloyed Cell with Screen-Printed Metallization}

Solar cells with a conventional design are presently the dominant cell type in large-scale industrial manufacturing [31]. The models presented here are based on values obtained from both the literature, as well as various industry sourced cells whose specific details remain hidden for commercial reasons. In general, there are several possible varieties of this cell type. Most notably, the substrate may be either multicrystalline (standard or high performance) or monocrystalline Czochralski (Cz). Here, we have chosen standard multicrystalline material to demonstrate both a simple bulk model for this material as well as how to incorporate an isotextured front surface. The emitter may be formed with either a "standard" or "high-efficiency" approach; see, for example, [32]. We have chosen the "standard" approach to demonstrate how to model the impact of $\mathrm{Si}-\mathrm{P}$ precipitation on cell performance. It should be noted that, particularly for conventional screen print cells on monocrystalline material, it is likely that the majority of production cells now use the highefficiency emitter approach. For the input parameters to such an emitter, see the passivated emitter rear cell (PERC) cell in the next section. Finally, the screen-print fingers themselves also have several varieties. This includes single print and double print, as well as an alternative in stencil printing. Since the overwhelming majority of production cells are currently manufactured by the first option, the inputs we present for the front contact represent a typical single-print 3 busbar $\mathrm{H}$ pattern with an average finger width that is consistent with the 2014 ITRPV [31].

The front-surface optical properties of these cells are dominated by the isotexture. Although this surface topology is rather irregular and depends strongly on the manufacturing process, it is possible to quantify the photogeneration and parasitic absorption of the cell with standard ray tracing, assuming a 3-D symmetry element with a top shape of a spherical cap spanning a characteristic angle [33]-[35]. The rear interface is approximated with a planar geometry, causing a moderate amount of scattering described with Phong's model [36].

The isotexturing also increases the surface area and, hence, the $J_{0}$ of the emitter, typically by a factor of about 1.2. In this simulation example, $J_{0}$ derived by detailed modeling in the planar simulation domain without correction factors consequently needs to be $167 \mathrm{fA} / \mathrm{cm}^{2}$ to represent the target value of $200 \mathrm{fA} / \mathrm{cm}^{2}$. This increase in $J_{0}$ cannot be reproduced by simply increasing the SRH recombination velocity $S_{\mathrm{p}}$ of the front surface and the capture cross section $\sigma_{\mathrm{p}}$ of the inactive phosphorus by a factor of 1.2, because the limited carrier collection efficiency causes nonlinearities. In our example, a suitable multiplication factor turned out to be 1.73 (coincidentally the surface area enhancement factor of ideal pyramidal texture). This quantifies $V_{\text {oc }}$ rather precisely, but then underestimates the internal quantum efficiency in the UV and blue part of the spectrum. For the conductive boundary modeling, we therefore do not use the collection efficiency resulting from the detailed modeling of this particular emitter but, rather, a typical constant value of 0.85 [32], [37].

The "standard" heavily doped emitter is modeled using both a profile of active as well as inactive dopants as shown in Fig. 6 in Appendix B. The difference between these two profiles is inactive phosphorus (interstitial $\mathrm{P}$ clusters and possibly various forms of precipitates), which then leads to a highly localized degradation of the carrier lifetime. The full details of these profiles and their impact on recombination can be found in [38] 
and [39]. Notably, we neglect the effects of metal paste etching and silver crystallites under at the contacted emitter regions, but rather assume identical doping profiles with thermal surface recombination velocity. This may result in an unrealistically low $J_{0}$ for the contacted emitter, which has however minor influence on the simulated cell characteristics.

Similarly, we present a detailed model for the back surface field. This work has assumed that the boron concentration of the screen-printed pastes is negligible (which may not be true for high-efficiency rear-side pastes), and therefore, the BSF is entirely formed from Al. The exact profile used for the BSF is obtained from [40] and is shown in Fig. 7 in Appendix B. The modeling accounts for incomplete ionization and $\mathrm{Al}-\mathrm{O}$ complex recombination via the models presented in [41], with defect parameters taken from [42].

The lifetime within the bulk of multicrystalline material is dominated by a variety of defects, which are expected to vary greatly from wafer to wafer. For this reason, we propose here a simplification which will allow the simulation of the basic underlying performance of the device architecture itself. Neglected are the spatial variations of the bulk lifetime due to the different grains, grain boundaries, edge contaminated regions, and defect clusters. It is worth noting that the relative impact of all of the inputs will be modulated by this underlying material quality. However, specific strategies to account for this are beyond the scope of this paper. Thus, to provide a basic model for the bulk of a standard mc-Si wafer, we use here a single SRH defect at mid-band with $\tau_{\mathrm{n}}=\tau_{\mathrm{p}}=75 \mu \mathrm{s}$. The input parameters for the conventional cell are summarized in Table II.

\section{B. Passivated Emitter Rear Cell (Industry Typical Properties): Monocrystalline p-Type Cell With Local Al-BSF and Screen-Printed Metallization}

PERC cells are presently being introduced into mass production to increase cell efficiency. They improve upon the conventional cell (described above) by replacing the rear-surface fullarea Al-BSF with a stack of passivation layers and localized contacts; in order to gain benefits from the improved rear, the emitter must be improved as well. The localized contact regions are typically formed by locally laser ablating the rear dielectric film and then firing specialized screen-printed Al paste through the openings to form localized BSF regions.

In principle, the rear of the PERC cell architecture is somewhat independent of the choice of front-surface properties. As such, it would be possible to substitute the values provided here with those from the previous section. However, the low recombination achieved at the rear surface means that this type of cell is more sensitive to increased recombination in the bulk or at the front surface. We, therefore, model it with a "high-efficiency" emitter and good-quality monocrystalline $\mathrm{Cz}$ silicon substrates. The SRH lifetime parameters are chosen from [47] and do not include the recent improvements made in stabilizing the B-O complex.

The optical losses are calculated with standard ray tracing assuming a classic single $\mathrm{KOH}$ textured pyramid but random shifts of the rays to mimic the random placement of the pyra- mids. The optical properties of the rear interface are important in PERC cells. In this example, the scattering and parasitic absorption are ray traced with the tilted-mirrors model [48], [49]. The optical properties depend strongly on the thickness of the dielectric between $\mathrm{Si}$ and Al. Here, a $100-\mathrm{nm} \mathrm{SiN}_{x}$ is chosen (having the same refractive index as the front AR coating for simplicity), on top of $10-\mathrm{nm}$ plasma-enhanced chemical vapor deposition (PECVD) $\mathrm{AlO}_{x}$.

For confidentiality reasons, the "high-efficiency" emitter used here does not represent an actual manufactured one. It is derived from the "standard" emitter as described in the above conventional cell by omitting the first $30 \mathrm{~nm}$ of the doping profile, representing an etch-back process commonly used in industry for this purpose, and as such might be significantly different to typical high-efficiency emitter profiles. The $\mathrm{KOH}$-texturing increases the surface area of the emitter by a factor of approximately 1.7. It is shown in [50], however, that the accompanying increase in $J_{0}$ can be reasonably compared with the increase in case of isotexturing. Therefore, for calculating the SRH recombination velocity $S_{\mathrm{p}}$ of the front side and the capture cross section $\sigma_{\mathrm{p}}$ of the inactive phosphorus, we choose a texture multiplier of 1.35, which is used to account for the increase in $J_{0}$ of many industrial emitters after isotexturing. Detailed modeling of this virtual "high-efficiency" emitter results in a typical decrease of $J_{0}$ compared with the standard emitter (while still having a slightly higher than typical absolute value) but with a notably relatively high sheet resistance $R_{\text {sheet }}$. Due to the latter, the simulated resistive losses in the emitter may be larger than typical. As explained in the conventional cell above, the collection efficiency is set independent from the detailed modeling results to a value of 0.95 typical for a high-efficiency emitter.

Of critical importance to the performance of a PERC cell is the design of the rear-side contact pattern. The localized BSF regions are in this case formed as lines but are often also formed as an array of points. The selection of the width and pitch of these lines is a tradeoff between resistive and recombination losses. From the literature, it is clear that there is a wide variety of values for the recombination at the rear surface and within these localized contact regions. However, insufficient reliable data have been published to date to deduce a justifiable range for $J_{0}$ of the localized BSF, which is therefore omitted from Table III despite its large variation. The amount of recombination within the device may also be affected by void formation, which is not accounted for here. In this example, we neglect lateral variations within the localized BSF regions and apply the full-area Al-BSF profile from the conventional cell above thinned by $3 \mu \mathrm{m}$ to represent the typically shallower depth and higher recombination of a localized BSF. The input parameters for the PERC cell are summarized in Table III.

\section{C. n-PASHA (ECN): Bifacial n-Type Cell with Screen- and Stencil-Printed Metallization}

The n-PASHA cell developed at ECN [53], along with its industrial equivalents PANDA of Yingli Solar [54], is one of the most prominent industrial bifacial cells. The models and input sets presented here for the n-Pasha cell have been chosen 
TABLE III

INPUT PARAMETER SET FOR THE PERC CELL

\begin{tabular}{|c|c|}
\hline \multicolumn{2}{|r|}{ cell design } \\
\hline $\begin{array}{l}\text { cell size } \\
\text { front } \\
\text { rear }\end{array}$ & $\begin{array}{l}156 \mathrm{~mm} \times 156 \mathrm{~mm} \text { pseudosquare thickness } 180 \mu \mathrm{m} \\
\text { homogeneous } \mathrm{n}^{+} \text {diffusion H-pattern screen-printed metallization } \\
\text { undiffused and passivated line local } \mathrm{p}^{+} \text {alloyed Al-BSF, } 120 \mu \mathrm{m} \\
\text { wide, } 850 \mu \mathrm{m} \text { pitch }\end{array}$ \\
\hline \multicolumn{2}{|r|}{ optics } \\
\hline $\begin{array}{l}\text { front dielectric } \\
\text { front } \\
\text { morphology }\end{array}$ & $\begin{array}{l}70-\mathrm{nm} \mathrm{PECVD} \mathrm{SiN}_{\mathrm{x}}[43](n=1.99) \\
\text { random pyramids }\end{array}$ \\
\hline rear dielectrics & $\begin{array}{l}\text { 10-nm PECVD } \mathrm{Al}_{2} \mathrm{O}_{3} \text { [51] (inner film) 100-nm PECVD SiN } \mathrm{x}_{\mathrm{x}} \text { [43] } \\
(n=1.99)(\text { outer film) }\end{array}$ \\
\hline rear morphology & $\begin{array}{l}\text { modeled by "strong planarization" case of the tilted-mirrors model } \\
\text { [48], [49] }\end{array}$ \\
\hline $\begin{array}{l}\text { busbar shading } \\
\text { fraction }\end{array}$ & $2.5 \%$ \\
\hline $\begin{array}{l}\text { effective finger } \\
\text { shading width }\end{array}$ & $42 \mu \mathrm{m}$ (finger width times $70 \%$ optical shading factor [44]) \\
\hline \multicolumn{2}{|r|}{ metal grid } \\
\hline front fingers & $\begin{array}{l}91 \text { fingers with } 1.7 \mathrm{~mm} \text { pitch, } 60 \mu \mathrm{m} \text { wide, and } 12 \mu \mathrm{m} \text { high, } \\
\text { rectangular shape } \\
\text { Ag-paste with } 4.5-\mu \Omega \cdot \mathrm{cm} \text { resistivity } \\
\text { contact resistivity } 2 \mathrm{~m} \Omega \cdot \mathrm{cm}^{2} \\
\text { lumped series resistance: } 0.252 \Omega \cdot \mathrm{cm}^{2}\end{array}$ \\
\hline front busbars & $\begin{array}{l}3 \text { busbars, } 1300-\mu \mathrm{m} \text {-wide and } 15-\mu \mathrm{m} \text {-high } \\
\text { Ag-paste with } 4.5-\mu \Omega \cdot \mathrm{cm} \text { resistivity } \\
\text { lumped series resistance: neglected }\end{array}$ \\
\hline rear metal & $\begin{array}{l}\text { full area Al-paste with } 35-\mu \Omega \cdot \mathrm{cm} \text { resistivity, } 30-\mu \text { m-high } \\
\text { contact resistivity } 5-\mathrm{m} \Omega \cdot \mathrm{cm}^{2} \\
\text { lumped series resistance: neglected }\end{array}$ \\
\hline \multicolumn{2}{|r|}{ electrical properties } \\
\hline bulk & $\begin{array}{l}\text { 2- } \Omega \cdot \mathrm{cm} \text { p-type } \mathrm{CZ} \\
\text { mid-gap SRH lifetimes } \tau_{\mathrm{n}}=371 \mu \mathrm{s} \text { and } \tau_{\mathrm{p}}=3710 \mu \mathrm{s} \text { derived } \\
\text { from [47] }\end{array}$ \\
\hline $\begin{array}{l}\text { front } \mathrm{n}^{+} \\
\text {diffusion }\end{array}$ & $\begin{array}{l}\text { lumped inputs } \\
\text { sheet resistance } 162 \Omega(90-160)^{*} \\
\text { recombination parameter } J_{0} \\
\text { passivated: } 168 \mathrm{fA} / \mathrm{cm}^{2}(80-140) * \\
\text { contacted: } 595 \mathrm{fA} / \mathrm{cm}^{2}(400-700) \\
\text { depth } 0.36 \mu \mathrm{m} \\
\text { collection efficiency } 0.95 \\
\text { detailed inputs } \\
\text { doping profile } \\
\quad \text { total and active concentration from [38] with } 30-\mathrm{nm} \\
\quad \text { etch-back, see Appendix B } \\
\text { surface } S R H \\
\text { passivated: } S_{\mathrm{p}}=4.86 \times 10^{5} \mathrm{~cm} / \mathrm{s}, S_{\mathrm{n}}=1 \times 10^{7} \mathrm{~cm} / \mathrm{s} \text { (derived } \\
\text { from [39] with texture multiplier of } 1.35) \\
\quad \text { contacted: } S_{\mathrm{p}}=S_{\mathrm{n}}=1 \times 10^{7} \mathrm{~cm} / \mathrm{s} \text { (thermal velocity) } \\
\text { volume } S R H \\
\text { modeled via inactive phosphorus profile according } \\
\quad \text { to [39] and a texture multiplier of } 1.35\end{array}$ \\
\hline rear $\mathrm{p}^{+}$region & $\begin{array}{l}\text { lumped inputs } \\
\text { sheet resistance } 61-\Omega \\
\text { recombination parameter } J_{0}=795 \mathrm{fA} / \mathrm{cm}^{2} \\
\text { depth } 4 \mu \mathrm{m} \\
\text { collection efficiency } 0.9 \\
\text { detailed inputs } \\
\text { doping profile } \\
\quad \text { measured active concentration from [40] with incomplete } \\
\quad \text { ionization model from [45], 3- } \mu \text { m etch-back; see Appendix B } \\
\text { surface } S R H \\
\quad S_{\mathrm{p}}=S_{\mathrm{n}}=1 \times 10^{7} \mathrm{~cm} / \mathrm{s} \text { (thermal velocity) } \\
\text { volume } S R H \\
\text { modeled as in }[41] \text { with parameters in [42] }\end{array}$ \\
\hline
\end{tabular}

TABLE III

(CONTINUED)

\begin{tabular}{|c|c|}
\hline passivated rear & $\begin{array}{l}\text { lumped inputs } \\
\text { recombination parameter } J_{0}=13.1 \mathrm{fA} / \mathrm{cm}^{2} \\
\text { detailed inputs } \\
\text { surface } S R H \text { and charge } \\
\quad S_{\mathrm{p}}=78 \mathrm{~cm} / \mathrm{s}, S_{\mathrm{n}}=1.08 \times 10^{5} \mathrm{~cm} / \mathrm{s}, Q=-3 \times \\
\quad 10^{12} \mathrm{~cm}^{-2} \text { from }[52] \text { with } D_{\mathrm{it}}=6 \times 10^{17} \mathrm{~cm}^{-2} \cdot \mathrm{eV}^{-1} \\
\quad \text { (midgap) }\end{array}$ \\
\hline
\end{tabular}

${ }^{*}$ The lumped input parameters for the emitter being out-of-range of typical values is caused by the enforced consistency with the detailed modeling, which input parameters deviate from an industry-typical high-efficiency emitter due to confidentiality reasons (see text for more information)

such that the optical, recombination, and resistive properties of laboratory cells manufactured at ECN are well represented. A slightly different description of the n-Pasha cell was given in [55].

The reported $J_{0}$ values were taken from lifetime measurements. The reported $S_{\mathrm{p} 0}, S_{\mathrm{n} 0}$ values were adapted to obtain the measured $J_{0}$. To account for the textured surface, an enhancement factor of 1.7 was used both for the Auger and surface recombination. The present parameters still suggest that optimization of the surface is possible.

It was found that in order to describe recombination at the contacts, a local etch-back of the profile must be assumed [49]. Such a uniform effective etch-back is an idealization of the actual damage that is caused by fire-through metallization, especially under the $\mathrm{Ag}-\mathrm{Al}$ contacts on the emitter. The effective etch depths are chosen to match the difference in implied $V_{\mathrm{oc}}$ of the cell before metallization and the measured $V_{\text {oc }}$ after metallization.

The n-Pasha cell has a random pyramid texture at the front and rear surfaces. A textured rear is required to obtain a high bifaciality factor. In the present model, the rear dielectric layer is not treated explicitly. A Lambertian rear reflector was assumed, and the reflectivity was adapted to match the measured $J_{\mathrm{sc}}$. In the assumption for the rear reflector, two opposing effects are lumped: the significant free-carrier absorption within the two full-area diffusions, and the current gain from the reflective chuck used in the measurement.

Fig. 4 shows that the recombination at MPP is rather evenly distributed over the bulk, emitter and BSF, although recombination at the metallized areas is relatively large. Further optimization of contacts and diffused regions would make the cell efficiency more dependent on the bulk quality. The rear $\mathrm{n}+$ diffusion of the n-Pasha cell has a large contribution to the resistive losses, which is accepted in order to keep the shaded area small for high bifaciality. The input parameters for the n-PASHA cell are summarized in Table IV.

\section{Heterojunction Technology (Projected): n-Type Heterojunction Cell with Screen-Printed Metallization}

The HJT was successfully first industrialized by Sanyo, now Panasonic, and holds the current efficiency record for a 
TABLE IV

INPUT PARAMETER SET FOR THE N-PASHA CELL

\begin{tabular}{ll}
\hline \hline & \multicolumn{1}{c}{ cell design } \\
\hline cell size & $\begin{array}{l}156 \mathrm{~mm} \times 156 \mathrm{~mm} \text { pseudosquare } \\
\text { thickness } 180-\mu \mathrm{m} \\
\text { homogeneous } \mathrm{p}+\text { diffusion } \\
\text { Front }\end{array}$ \\
Rear & $\begin{array}{l}\text { Hotprern stencil-printed metallization } \\
\text { homogeneous } \mathrm{n}+\text { diffusion } \\
\text { H-pattern screen-printed metallization }\end{array}$ \\
\hline
\end{tabular}

\begin{tabular}{ll}
$\begin{array}{l}\text { front and rear } \\
\text { dielectric } \\
\text { front and rear } \\
\text { morphology } \\
\text { rear optics }\end{array}$ & $\begin{array}{l}\text { 70-nm PECVD } \operatorname{SiN}_{x}[43](n=1.99) \\
\text { height } \\
\text { modeled by Lambertian rear reflector with effective } R=0.78 \\
\text { and } T=0.22 \text { to match } J_{\mathrm{sc}} \text { measured with a reflective chuck. }\end{array}$ \\
$\begin{array}{l}2.86 \% \\
\begin{array}{l}\text { busbar shading } \\
\text { fraction } \\
\text { effective finger } \\
\text { shading width }\end{array}\end{array}$ & $31.5 \mu \mathrm{m}$ (finger width times $70 \%$ optical shading factor [44]) \\
\hline \multicolumn{1}{c}{ metal grid } \\
\hline
\end{tabular}

front fingers $\quad 72$ fingers with $2.05-\mathrm{mm}$-pitch, $45-\mu \mathrm{m}$-wide, and 30- $\mu$ m-high

Al-Ag-paste with $4.7-\mu \Omega \cdot \mathrm{cm}$ resistivity

contact resistivity $3-\mathrm{m} \Omega \cdot \mathrm{cm}^{2}$ (estimate)

lumped series resistance: $0.185 \Omega \mathrm{cm}^{2}$

front and rear $\quad 3$ busbars, $1500-\mu \mathrm{m}$-wide and $10-\mu \mathrm{m}$-high

busbars Ag-paste with $3-\mu \Omega \cdot \mathrm{cm}$ resistivity, noncontacting

lumped series resistance: neglected

rear fingers $\quad 144$ fingers with 1.025 -mm-pitch, $100-\mu$ m-wide, and

10- $\mu$ m-high

Ag-paste with $3-\mu \Omega \cdot \mathrm{cm}$ resistivity

contact resistivity $3-\mathrm{m} \Omega \cdot \mathrm{cm}^{2}$ (estimate)

lumped series resistance: $0.083 \Omega \cdot \mathrm{cm}^{2}$

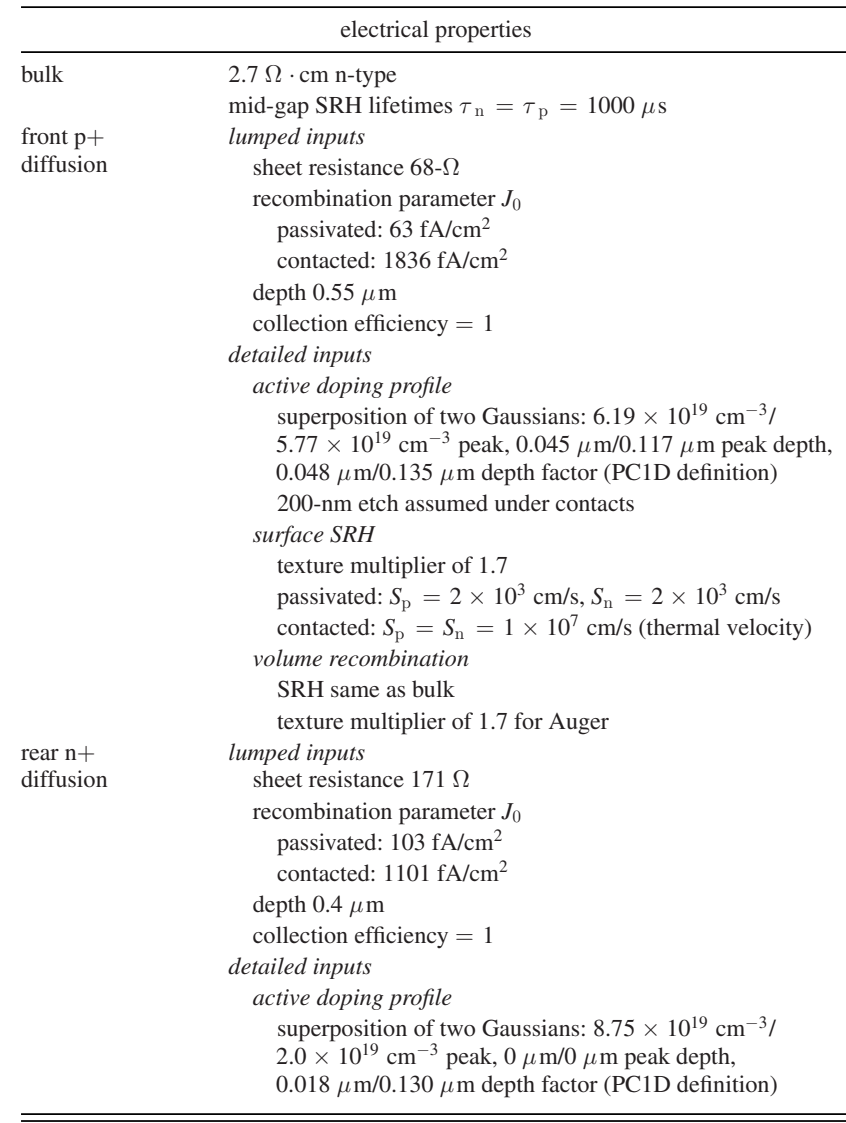

TABLE IV

(CONTINUED)

nonconcentrated single-junction silicon solar cell of $25.6 \%$ using an IBC design [56]. With a conventional bifacial design, the corresponding heterojunction cell efficiency record (again achieved by Panasonic) is $24.7 \%$ [57]. As a comprehensive characterization and description of their device properties is publicly not available, the stated input parameter set describes a theoretical cell, which essentially combines cell design and electrical properties of thin-film a-Si:H layers and interfaces as optimized, measured, and simulated at SERIS [58], [59], with the optical a-Si:H properties and the TCO properties as published by EPFL [60], [61]. For best consistency, we also employ a value for contact resistivity between Ag-paste fingers on this particular TCO, as published in [62].

While not representing a physical manifestation of a real cell, all individual properties and cell characteristics are within reasonable limits of what is typically achieved at research institutes, highlighting common characteristics and loss mechanisms of HJT cells. A notable deviation of the presented laboratory cell design from an industrial HJT design is the full-area silver-based rear metallization, which in industry is commonly replaced by an H-pattern screen printed metallization for bifaciality and cost reasons.

The corresponding simulation input parameters are calibrated twofold: first using published input parameters for heterojunction solar cells by Rahmouni [63] reproducing published results from Panasonic [64] (reporting 20.4\% efficiency at that time) (see [Table 4.1, 50]), and second, calibrated toward measured injection-dependent effective carrier lifetime curves of symmetrically passivated silicon wafers using heterojunction silicon thin-film layers as developed and characterized at SERIS (see [Tables 4.2 and 4.4, 50]) stated also in Appendix A.

Please note that especially the optical properties of the TCO have to be improved in order reach higher short-circuit current densities (i.e., compare $J_{\mathrm{sc}}$ values in the order of $37 \mathrm{~mA} \cdot \mathrm{cm}^{-2}$ as reported by Rahmouni/Taguchi [63], [64] and also if using the optical TCO and a-Si:H data published by EPFL [60], [61] to a $J_{\mathrm{sc}}$ of $39.5 \mathrm{~mA} \cdot \mathrm{cm}^{-2}$, as recently reported by Panasonic [57]). Furthermore, the modeling assumes that the workfunction match of the TCO has been achieved, and thus, no TCOinduced band-bending reaching into the silicon bulk has to be considered. The optical properties depend strongly on the thickness and dielectric properties of the TCO and a-Si:H used. Here, a 70-nm-thick ITO is chosen as TCO, i.e., using optical TCO and a-Si:H data as published by Black and McIntosh [52]. Again note that currently the calibration toward measured lifetime samples 
did not consider TCO. After a subsequent TCO optimization, a slight decrease in $V_{\mathrm{Oc}}$ but an increase in $J_{\mathrm{Sc}}$ can be expected.

In the conductive boundary modeling approach, the strongly nonideal effective recombination at the c-Si/a-Si interfaces requires to define an injection-dependent boundary recombination parameter $J_{0}$, fitted to lifetime measurements as explained above and parameterized as given in Appendix C. Also note that in the conductive boundary approach, the resistive losses due to current transport through the a-Si:H layers is accounted for by a (measured) contribution to the lumped series resistance.

Looking at the current loss analysis as sketched in Fig. 3, the front-contact shading is higher compared with other cells, as the grid has not been optimized toward a TCO (which is still to be optimized) yet. As expected for heterojunction solar cells, there is significant parasitic front-film absorption loss (TCO and a-Si:H), thereby reducing $J_{\mathrm{sc}}$. The input parameters for the HJT cell are summarized in Table V.

\section{E. PERL (UNSW): Record Efficiency Laboratory Silicon Solar Cell Fabricated at UNSW}

The PERL cell, conceived and fabricated at the University of New South Wales (UNSW), held the 1-sun efficiency record of $25.0 \pm 0.5 \%$ between 1998 and 2014 [65], [66]. It retains the 1 -sun record for a diffused-junction silicon solar cell. The input parameters presented here are based on the data published in [67]-[70].

Notably, there is a discrepancy between the $J_{\mathrm{sc}}$ of the $I-V$ measurement and the $J_{\mathrm{Sc}}$ calculated from the QE and reflection measurements. The latter is $0.8 \mathrm{~mA} / \mathrm{cm}^{2}$ lower, although still within the uncertainty quoted for the $I-V$ measurement. The discrepancy might be accounted for by differences in the optics between the location of the QE, reflection, and $I-V$ measurements. For example, the tiler's pattern introduces a strong periodic dependence of the light trapping on cell width (amplitude of $0.4 \mathrm{~mA} / \mathrm{cm}^{2}$ and a period of $\sim 4 \mu \mathrm{m}$ ); thus, a variable cell width introduces spatially variable light trapping. Other spatial variations could arise from variability in scattering associated with roughened surfaces as well as variability in the planar regions between pyramids. In Table VI, the input parameters result in a $J_{\mathrm{sc}}$ that lies between that determined from $I-V$ and QE measurements.

The refractive index of the original films was not published; here, we use data published in [44] and [64] to represent the original films, which yields a reflection curve consistent with the experimental curve for the stated film thicknesses.

Due to the large ratio of the perimeter-to-active cell area, the perimeter losses of the PERL cell are significant and constitute a loss in efficiency of about $0.2-0.3 \%$, which is not taken into account in the results of Section IV. The input parameters for the PERL cell are summarized in Table VI.

\section{F. IBC (ANU): High-Efficiency Laboratory Interdigitated-Back-Contact Solar Cell Fabricated at ANU}

ANU's IBC cell with an efficiency of $24.4 \pm 0.7 \%$ [77] is currently the most efficient IBC cell fabricated at a research institute. Although IBC cells with a higher efficiency have been
TABLE V

INPUT PARAMETER SET FOR THE HJT CELL

\begin{tabular}{|c|c|}
\hline \multicolumn{2}{|r|}{ cell design } \\
\hline $\begin{array}{l}\text { cell size } \\
\text { front }\end{array}$ & $\begin{array}{l}156 \mathrm{~mm} \times 156 \mathrm{~mm} \text { pseudosquare thickness } 150 \mu \mathrm{m} \\
\text { full-area i-a-Si:H/p-a-Si:H/TCO stackH-pattern screen-printed } \\
\text { metallization }\end{array}$ \\
\hline rear & $\begin{array}{l}\text { full-area i-a-S:Hi/n-a-Si:H/TCO stackfull-area screen-printed } \\
\text { metallization }\end{array}$ \\
\hline \multicolumn{2}{|r|}{ optics } \\
\hline front TCO & 70-nm ITO with $2 \times 10^{20} \mathrm{~cm}^{-3}$ free carrier density [61] \\
\hline front a-Si:H & $\begin{array}{l}\text { 3.5-nm i-a-Si:H/6-nm p-a-Si:H, thicknesses from [58], optical } \\
\text { properties from [60] }\end{array}$ \\
\hline rear TCO & 150-nm ITO with $6.5 \times 10^{19} \mathrm{~cm}^{-3}$ free carrier density [61] \\
\hline rear a-Si:H & $\begin{array}{l}\text { 3.5-nm i-a-Si:H/20-nm n-a-Si:H, thicknesses from [58], optical } \\
\text { properties from [60] }\end{array}$ \\
\hline $\begin{array}{l}\text { front and rear } \\
\text { morphology }\end{array}$ & $\begin{array}{l}\text { random pyramids, } 54.3^{\circ} \text { characteristic angle, } 5-\mu \mathrm{m} \text { texture } \\
\text { height }\end{array}$ \\
\hline $\begin{array}{l}\text { busbar shading } \\
\text { fraction }\end{array}$ & $2.86 \%$ \\
\hline $\begin{array}{l}\text { effective finger } \\
\text { shading width }\end{array}$ & $77 \mu \mathrm{m}$ ( = finger width times $70 \%$ effective shading [44]) \\
\hline \multicolumn{2}{|r|}{ metal grid from [59] } \\
\hline front fingers & $\begin{array}{l}86 \text { fingers with } 1.7 \text {-mm-pitch, } 110-\mu \mathrm{m} \text {-wide, and } 13-\mu \text { m-high } \\
\text { Ag-based polymer paste with } 7.15-\mu \Omega \cdot \mathrm{cm} \text { effective resistivity } \\
\text { (derived from measured sheet resistance and assuming } \\
\text { rectangular cross sectional profile) } \\
\text { contact resistivity } 10 \mu \Omega \cdot \mathrm{cm}^{2} \text { (from [62]) } \\
\text { lumped series resistance: } 0.195 \Omega \mathrm{cm}^{2}\end{array}$ \\
\hline front busbars & $\begin{array}{l}3 \text { busbars, } 1500-\mu \mathrm{m} \text {-wide and } 13-\mu \mathrm{m} \text {-high } \\
\text { Ag-based polymer paste with } 7.15-\mu \Omega \cdot \mathrm{cm} \text { effective resistivity } \\
\text { lumped series resistance: neglected }\end{array}$ \\
\hline rear metal & $\begin{array}{l}\text { full area Ag-based polymer paste } \\
\text { contact resistivity } 10 \mu \Omega \cdot \mathrm{cm}^{2} \text { (from [62]) } \\
\text { lumped series resistance: negligible }\end{array}$ \\
\hline \multicolumn{2}{|r|}{ electrical properties } \\
\hline bulk & $\begin{array}{l}5-\Omega \cdot \mathrm{cm} \text { n-type } \\
\text { mid-gap SRH lifetimes } \tau_{\mathrm{n}}=1000 \mu \mathrm{s}, \tau_{\mathrm{p}}=10000 \mu \mathrm{s}\end{array}$ \\
\hline $\begin{array}{l}\text { front layers and } \\
\text { interfaces }\end{array}$ & $\begin{array}{l}\text { lumped inputs } \\
\text { p }+ \text { boundary with sheet resistance } 150 \Omega \text { (calculated from } \\
\text { electron density and mobility given in [61]) } \\
\text { parameterization of injection dependent recombination } \\
\text { parameter } J_{0} \text { as measured and derived at SERIS, see } \\
\text { Appendix A3 } \\
\text { Contribution to lumped series resistance of } 0.16 \Omega \cdot \mathrm{cm}^{2} \\
\text { detailed inputs } \\
\text { summarized in [Tables } 4.2 \text { and } 4.4, \text { p. } 85 / 88,58] \text {; see } \\
\text { Appendix A1 }\end{array}$ \\
\hline $\begin{array}{l}\text { rear layers and } \\
\text { interfaces }\end{array}$ & $\begin{array}{l}\text { lumped inputs } \\
\mathrm{n}+\text { boundary, no value for sheet resistance required due to } \\
\text { full area contact } \\
\text { parameterization of injection dependent recombination } \\
\text { parameter } J_{0} \text { as measured and derived at SERIS; see } \\
\text { Appendix A3 } \\
\text { Negligible contribution to lumped series resistance } \\
\text { detailed inputs } \\
\text { summarized in [Tables } 4.2 \text { and } 4.4, \text { p. } 85 / 88,58] \text {; see } \\
\text { Appendix A1 }\end{array}$ \\
\hline
\end{tabular}

published by Sunpower (25.0\% [78]) and Panasonic (25.6\% with heterojunction technology [56]), a comprehensive characterization and description of their properties is not publicly available, and consequently, input parameter sets of commercial IBC cells are not presented in this work.

The properties of ANU's IBC cell have been analyzed extensively and presented in [10], [77], [79], and [80]. The largest unknown in the input parameter set is the bulk lifetime of the device as it could not be measured nondestructively. The value presented in [77] was deduced by fitting the measured $I-V$ curve 
TABLE VI

INPUT PARAMETER SET FOR THE PERL CELL

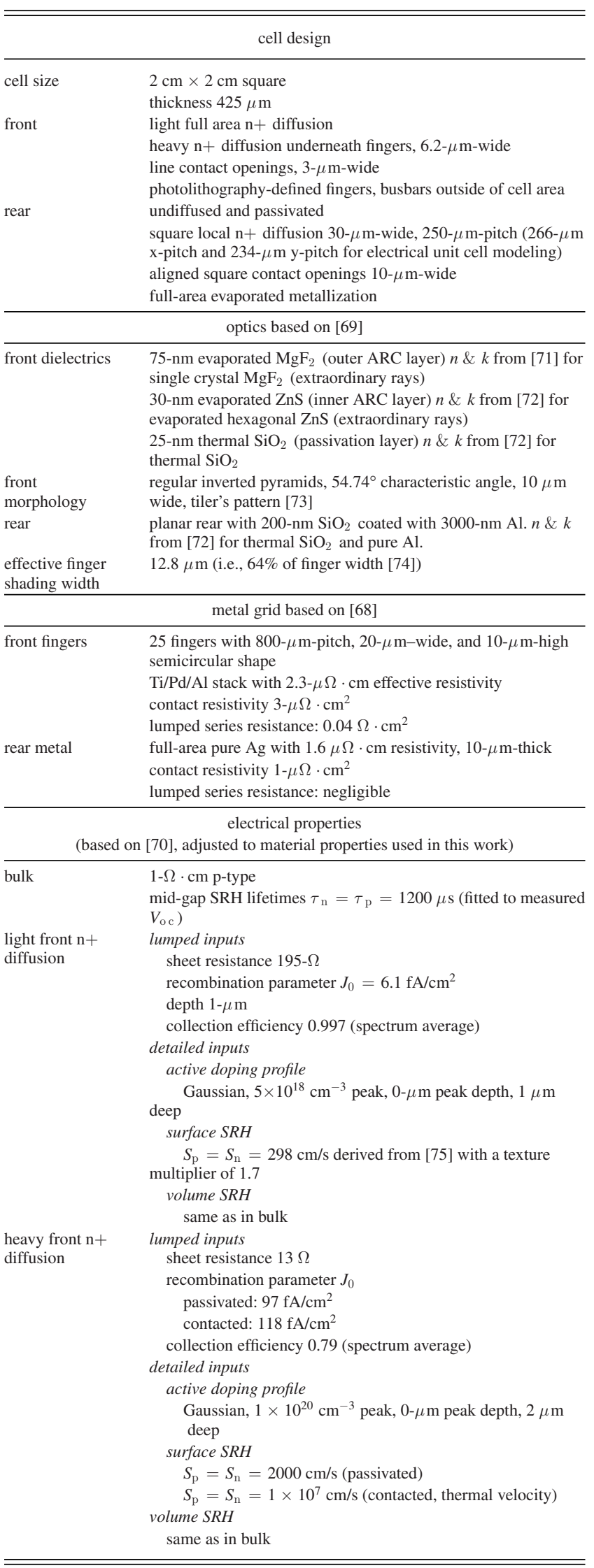

TABLE VI

(CONTINUED)

to 3-D simulation $I-V$ curve where the optical and surface recombination values are experimentally determined.

Some $J_{0}$ values presented in [77] have been slightly updated in this work to attain greater consistency, which notably required a reduction in the SRH lifetime in the bulk from 5 to $3 \mathrm{~ms}$ for a better overall agreement with measurements. There also exists some discrepancy between the measured BSF sheet resistance of $19 \Omega / \mathrm{sq}$ and simulation parameters in Table VII, to enable a good fit to the measured $J_{0}$ [77], which could otherwise not be achieved using any reasonable assumption for the doping profile. This discrepancy is likely a combination of experimental error in the sheet resistance and $J_{0}$ measurements. The change of sheet resistance is deemed insignificant to the internal resistance calculations due to the BSF being a 30- $\mu$ m diameter local diffusion around the contacts; we, therefore, choose to fit the measured $J_{0}$ more accurately than the measured $\rho_{\text {sq }}$.

Similar as for the PERL cell, the perimeter losses of ANU's IBC cells are significant and have been characterized to contribute to $0.24 \%$ of the absolute efficiency loss, facilitated by accurate 3-D simulation based on the measured optical, electronic, and physical properties [77]. Since the simulation parameters do not include perimeter loss, this is a significant contributor to the observed discrepancy between measured and simulated efficiency, as presented in Table VIII. The input parameters for the IBC cell are summarized in Table VII.

\section{RESULTS}

We now present the major outputs attained by simulating the solar cells using the input sets provided in the previous section. These outputs are presented as $I-V$ parameters (see Table VIII), $I-V$ curves (see Fig. 2), external quantum efficiency curves (see Fig. 3), current losses at maximum power (see Fig. 4), and resistive losses at maximum power (see Fig. 5). 
TABLE VII

INPUT PARAMETER SET FOR THE IBC CELL

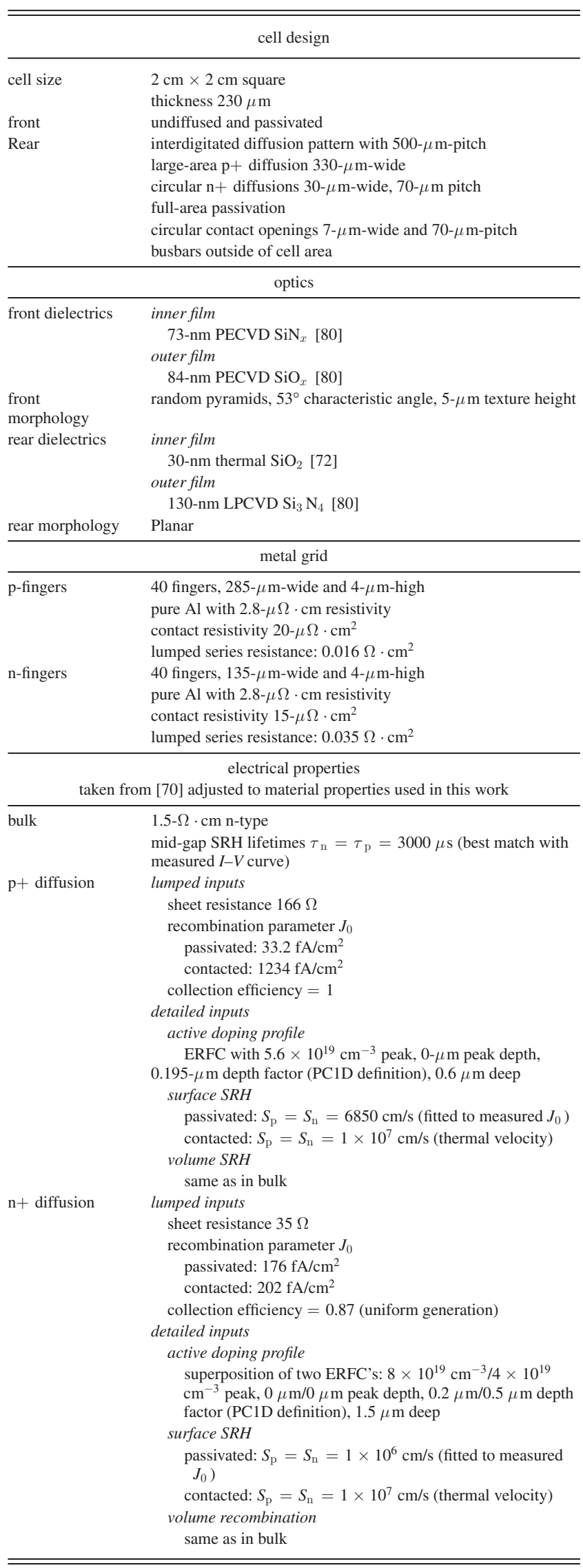

TABLE VII

(CONTINUED)

\begin{tabular}{ll}
\hline \hline passivated front & lumped inputs \\
& recombination parameter $J_{0}=4.6 \mathrm{fA} / \mathrm{cm}^{2}$ \\
detailed inputs & surface $S R H$ and charge \\
& $Q=5.6 \times 10^{11} \mathrm{~cm}^{-2}, S_{\mathrm{p}}=S_{\mathrm{n}}=2 \mathrm{~cm} / \mathrm{s}$ (derived from \\
& measured $J_{0}$ and charge, using case 3 in $[81]$ and a texture \\
multiplier of 1.7$)$
\end{tabular}

TABLE VIII

SumMary OF Light $J-V$ PARAMETERS SIMULATED By QUOKKA USING THE INPUT PARAMETERS PRESENTED IN SECTION III

\begin{tabular}{lcccc}
\hline \hline cell type & $\mathrm{V}_{\mathrm{oc}}[\mathrm{mV}]$ & $\mathrm{J}_{\mathrm{sc}}\left[\mathrm{mA} / \mathrm{cm}^{2}\right]$ & $\mathrm{FF}[\%]$ & $\eta[\%]$ \\
\hline Conventional-simulated & 626 & 35.2 & 79.8 & 17.6 \\
PERC-simulated & 655 & 39.8 & 79.4 & 20.7 \\
n-Pasha-simulated & 656 & 39.5 & 79.8 & 20.7 \\
n-Pasha-measured (ECN in-house) & 655 & 39.5 & 79.9 & 20.7 \\
HJT-simulated & 743 & 36.7 & 80.3 & 21.9 \\
PERL-simulated & 710 & 42.3 & 82.6 & 24.8 \\
PERL-measured [66] & 706 & 42.7 & 82.8 & 25.0 \\
IBC-simulated & 705 & 42.2 & 83.1 & 24.7 \\
IBC-measured [77] & 703 & 42.0 & 82.7 & 24.4 \\
\hline \hline
\end{tabular}

Measured data are included for input sets that were derived from a specific experimental solar cell.

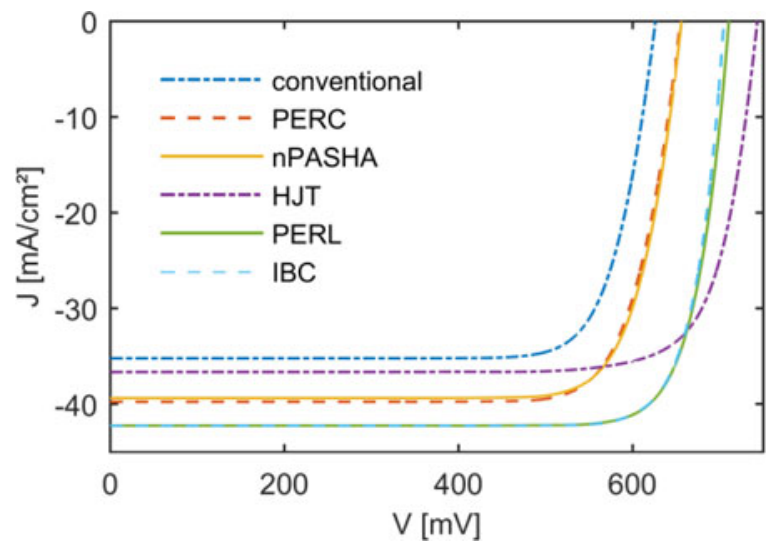

Fig. 2. Light $J-V$ curves of the different cell types produced by Quokka simulations using the input parameters sets from this work.

The electrical component to the simulations followed the conductive boundary approach and was conducted with Quokka. The input files can be downloaded from [2]. Equivalent simulations using the detailed modeling approach (not shown) yield the same cell $I-V$ parameters when the assumptions contained in the software are made identical and numerical errors are minimized.

We emphasize that it is not the purpose of the following comparisons to rate different cell technologies. Some of the simulations represent industrial designs while others represent 


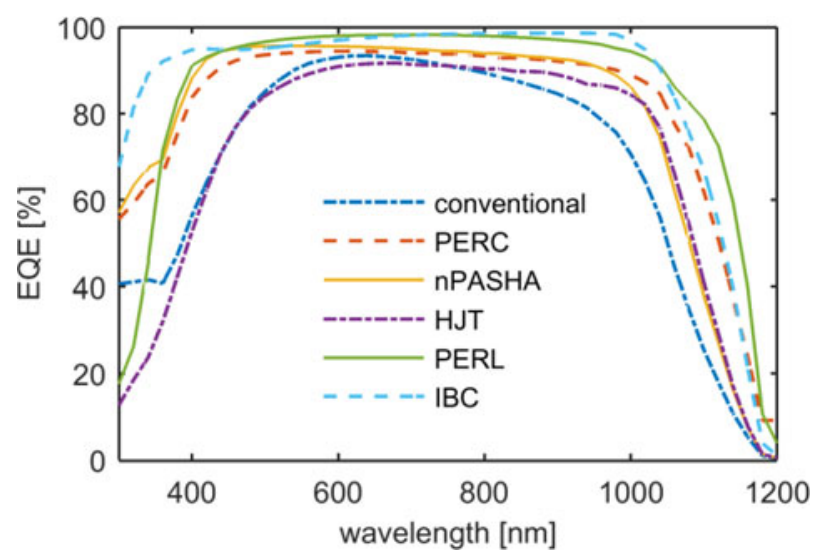

Fig. 3. External quantum efficiencies of the different cell types produced by Quokka simulations using the input parameters sets from this work; note that busbar shading is included.

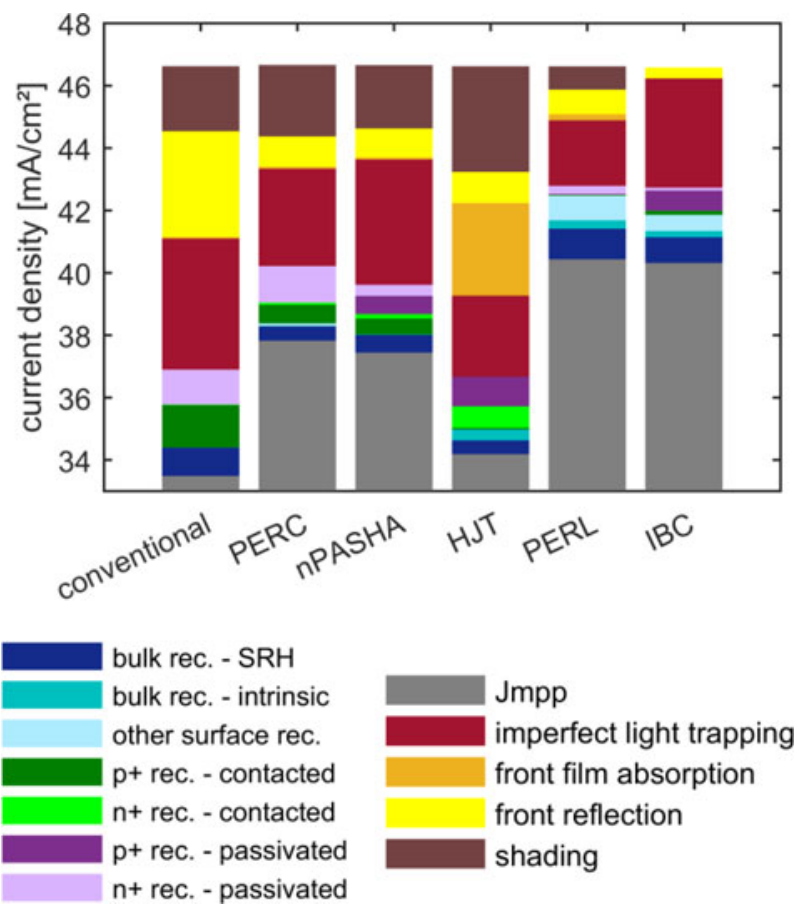

Fig. 4. Current loss breakdown at maximum power point, categorized into output current $J_{\mathrm{mpp}}$, recombination losses (left legend), and optical losses (right legend).

small-area laboratory solar cells (PERL, IBC). Thus, the results do not enable a meaningful comparison between the potential of the different cell architectures.

The results indicate that the simulated $I-V$ parameters agree closely with those of the n-Pasha, PERL, and IBC cells that were used to represent each respective cell type. By a comparison of the losses, the relative difference between the cell types is clear. For example, the higher $J_{\mathrm{sc}}$ of the PERL cells is due mainly to its low grid reflection and its superior light trapping. In addition, as another example, the advantage of the very high $V_{\text {oc }}$ attained by the heterojunction cell is partially offset by a high parasitic absorption in the front films.

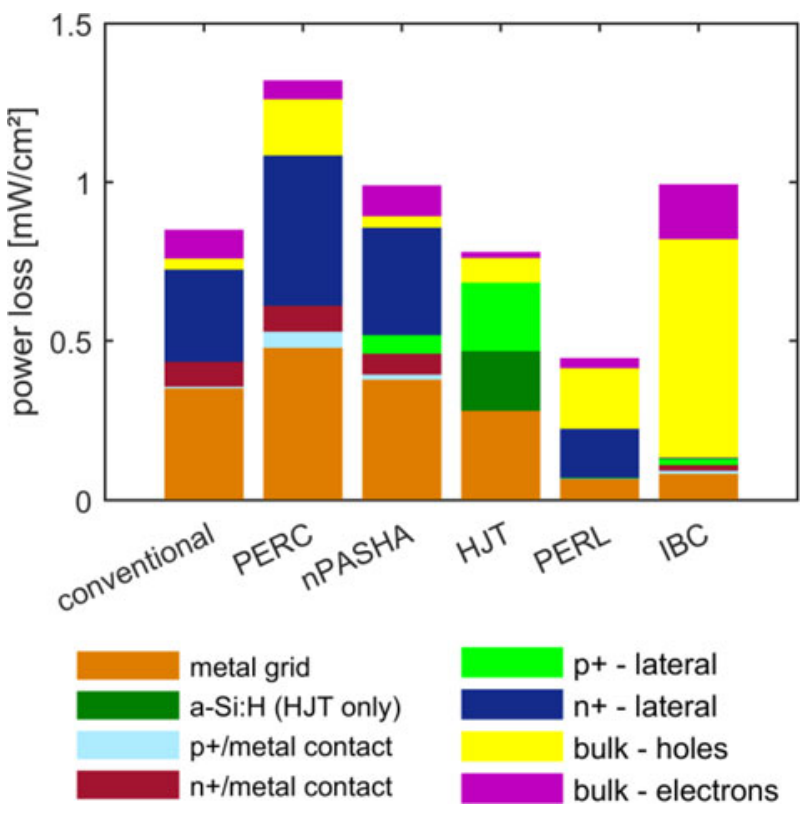

Fig. 5. Resistive power loss breakdown at maximum power point.

\section{CONCLUSION}

The many intricacies inherent to solar cell modeling make it difficult — but all the more valuable - to provide a reference point on which PV researchers can base their cell simulations.

In this work, we have contributed toward that goal by providing input parameter sets to simulate six specific c-Si solar cells, as well as the methodologies, assumptions, and physical models that accompany those inputs. As far as possible, we ensure the input parameters to be justified, typical, and to produce typical and measured cell characteristics.

Once more we emphasize that the parameter sets cannot be used to represent all cells of a given architecture. Some sets are specific to small-area laboratory-based cells, others to large-area industrial cells. In addition, due to variability in material quality and imperfect manufacturing repeatability, the parameter sets represent just one cell within a wide distribution of cells made by identical processing sequences. Moreover, changes to the input sets and methodologies cannot be made indiscriminately. Many input values depend on the choice of physical model, e.g., the values selected for the surface recombination velocities depend on the Auger and bandgap narrowing model. Simulation experts are encouraged to critically examine the justifications and substitute their own values where appropriate.

The input sets are accessible from an online library [2]. We hope that through examination, discussion, and experimentation, they will be continually reviewed, revised, and extended to provide an up-to-date reference for the PV community to simulate c-Si solar cells with ever more accuracy.

\section{APPENDIX A}

INPUT PARAMETERS FOR DETAILED MODELING OF THE HJT (PROJECTED) CELL

For better accessibility, excerpts of [Tables 4.2 and 4.4, 58] are given in Tables IX and X, which list the electrical input 
TABLE IX

EXCERPT OF [TABLE 4.2, 58]

\begin{tabular}{|c|c|c|c|}
\hline Parameters & a-Si:H(i) & a-Si:H(n) & a-Si:H(p) \\
\hline $\begin{array}{l}\text { Layer } \\
\text { thickness }(\mu \mathrm{m})\end{array}$ & 0.005 & 0.020 & 0.020 \\
\hline Electron affinity $(\mathrm{eV})$ & 4.0 & 4.0 & 4.0 \\
\hline Mobility gap (eV) & 1.75 & 1.80 & 1.75 \\
\hline $\begin{array}{l}\Delta \mathrm{E}_{\mathrm{V}} \text { with respect to } \\
\mathrm{c}-\mathrm{Si}(\mathrm{eV})\end{array}$ & -0.41 & -0.46 & -0.41 \\
\hline $\begin{array}{l}\text { Donor (acceptor) } \\
\text { doping }\left(\mathrm{cm}^{-3}\right)\end{array}$ & 0 & $1.45 \times 10^{19}$ & $\left(1.41 \times 10^{19}\right)$ \\
\hline $\begin{array}{l}\text { Effective DOS in CB } \\
\left(\mathrm{cm}^{-3}\right)\end{array}$ & $2 \times 10^{20}$ & $2 \times 10^{20}$ & $2 \times 10^{20}$ \\
\hline $\begin{array}{l}\text { Effective DOS in VB } \\
\left(\mathrm{cm}^{-3}\right)\end{array}$ & $2 \times 10^{20}$ & $2 \times 10^{20}$ & $2 \times 10^{20}$ \\
\hline $\begin{array}{l}\text { Urbach energy (VB } \\
\text { tail) }(\mathrm{eV})\end{array}$ & 0.045 & 0.05 & 0.05 \\
\hline $\begin{array}{l}\text { Urbach energy }(\mathrm{CB} \\
\text { tail) }(\mathrm{eV})\end{array}$ & 0.03 & 0.03 & 0.03 \\
\hline $\begin{array}{l}\text { Urbach tail pre- } \\
\text { factor }\left(\mathrm{cm}^{-3} \cdot \mathrm{eV}^{-1}\right)\end{array}$ & $4 \times 10^{21}$ & $4 \times 10^{21}$ & $4 \times 10^{21}$ \\
\hline $\begin{array}{l}\text { Electron/hole } \\
\text { mobility } \\
\left(\mathrm{cm}^{2} \cdot \mathrm{V}^{-1} \cdot \mathrm{s}^{-1}\right)\end{array}$ & $25 / 5$ & $20 / 4$ & $25 / 5$ \\
\hline $\begin{array}{l}\text { Gaussian defect } \\
\text { density }\left(\mathrm{cm}^{-3}\right)\end{array}$ & $9 \times 10^{16}$ & $2.75 \times 10^{19}$ & $2.63 \times 10^{19}$ \\
\hline \multicolumn{4}{|l|}{$\begin{array}{l}\text { Gaussian donor peak } \\
\text { position }\end{array}$} \\
\hline from VB $(e V)$ & 0.83 & 0.50 & 1.00 \\
\hline $\begin{array}{l}\text { Gaussian acceptor } \\
\text { peak position from } \\
\text { VB }(e V)\end{array}$ & 1.03 & 0.70 & 1.20 \\
\hline \multicolumn{4}{|l|}{$\begin{array}{l}\text { Neutral } \sigma \text { (for } \\
\text { Urbach tail and }\end{array}$} \\
\hline $\begin{array}{l}\text { Gaussian defects }) \\
\left(\mathrm{cm}^{2}\right)\end{array}$ & $10^{-15}$ & $6.5 \times 10^{-16}$ & $6.5 \times 10^{-16}$ \\
\hline $\begin{array}{l}\text { Charged } \sigma \text { (for } \\
\text { Urbach tail and } \\
\text { Gaussian defects) } \\
\left(\mathrm{cm}^{2}\right)\end{array}$ & $10^{-14}$ & $6.5 \times 10^{-15}$ & $6.5 \times 10^{-15}$ \\
\hline $\begin{array}{l}\text { Activation energy } \\
(\mathrm{eV})\end{array}$ & 0.83 & 0.20 & 0.30 \\
\hline $\begin{array}{l}\text { Correlation energy } \\
(\mathrm{eV})\end{array}$ & 0.20 & 0.20 & 0.20 \\
\hline
\end{tabular}

TABLE $X$

[TABLE 4.4, 58]

\begin{tabular}{lccc}
\hline \hline $\begin{array}{l}\text { Lifetime } \\
\text { structure }\end{array}$ & $\begin{array}{c}{[\mathrm{i} / \mathrm{N} / \mathrm{i}]} \\
\mathrm{c}-\mathrm{Si}(\mathrm{n}) / \mathrm{a}-\mathrm{Si}: \mathrm{H}(\mathrm{i})\end{array}$ & $\begin{array}{c}{[\mathrm{p} / \mathrm{i} / \mathrm{N} / \mathrm{i} / \mathrm{p}]} \\
\mathrm{c}-\mathrm{Si}(\mathrm{n}) / \mathrm{a}-\mathrm{Si}: \mathrm{H}(\mathrm{i}, \mathrm{p})\end{array}$ & $\begin{array}{c}{[\mathrm{n} / \mathrm{i} / \mathrm{N} / \mathrm{i} / \mathrm{n}]} \\
\mathrm{c}-\mathrm{Si}(\mathrm{n}) / \mathrm{a}-\mathrm{Si} / \mathrm{H}(\mathrm{i}, \mathrm{n})\end{array}$ \\
\hline Interface & $\mathrm{a}-\mathrm{Si} / \mathrm{c}-\mathrm{Si}$ interface & $\mathrm{a}-\mathrm{Si} / \mathrm{c}-\mathrm{Si}$ interface & $\mathrm{a}-\mathrm{Si} / \mathrm{c}-\mathrm{Si}$ interface \\
$D_{\mathrm{it}}$ & $4.6 \times 10^{12}$ & $5 \times 10^{10}$ & $5 \times 10^{10}$ \\
$\left(\mathrm{~cm}^{-2} \cdot \mathrm{eV}^{-1}\right)$ & & & \\
Charged $\sigma\left(\mathrm{cm}^{2}\right)$ & $10^{-18}$ & $10^{-18}$ & $10^{-18}$ \\
Neutral $\sigma\left(\mathrm{cm}^{2}\right)$ & $10^{-19}$ & $10^{-19}$ & $10^{-19}$ \\
\hline \hline
\end{tabular}

parameters for the detailed modeling of the a-Si:H films and interfaces as used for the HJT cell.

\section{APPENDIX B}

\section{DOPING PROFILES}

Figs. 6 and 7 show the emitter and BSF profiles of the conventional and PERC cell type assumed in this work.

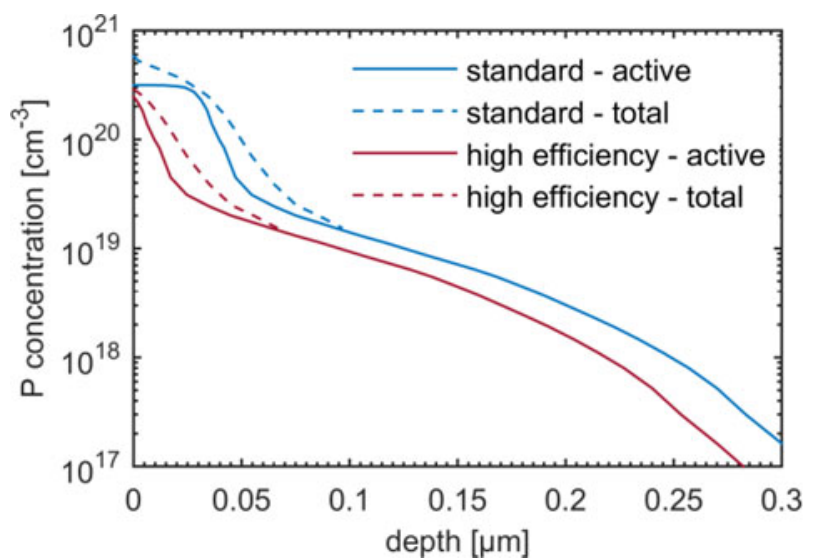

Fig. 6. Phosphorous concentration profiles of the front $\mathrm{n}^{+}$regions (emitter) of the "standard" (taken from [38]) and "high efficiency" emitter as used for the conventional and PERC cell type, respectively; note that the "high efficiency" profile is derived by thinning the "standard" profile by $30 \mathrm{~nm}$, representing an etch-back process.

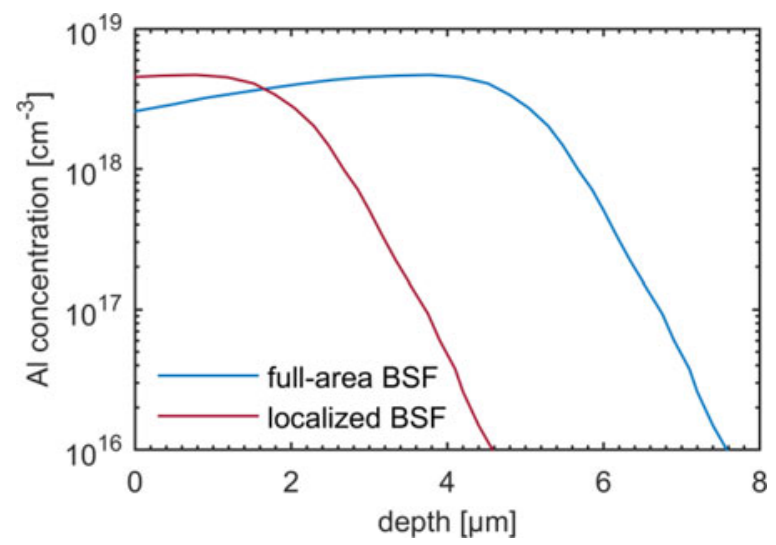

Fig. 7. Al concentration profiles of the rear $\mathrm{p}^{+}$regions (BSF) of the full-area BSF (conventional cell) and local BSF region (PERC cell); note that the local BSF profile is derived by thinning the full-area one by $3 \mu \mathrm{m}$.

\section{APPENDIX C \\ PARAMETERIZATIONS}

\section{A. Front and Rear $J_{0}$ of HJT (Projected) Cell}

The injection-dependent $J_{0}$ of the a-Si:H boundaries were extracted by numerical simulations of measured effective lifetime, which also match the detailed modeling, and numerically fitted by a second-order Fourier expression. Here, $\Delta p\left[\mathrm{~cm}^{-3}\right]$ denotes the excess carrier density at the boundary

$$
\begin{aligned}
J_{o, \text { front }\left[\frac{\mathrm{A}}{\mathrm{cm}^{2}}\right]=} & \left(\frac{8.27}{8.52}\right)^{2} \\
& \cdot 10^{\wedge}((1.367+0.7028 \cos (\log (\Delta p)) \\
& +0.2459 \sin (\log (\Delta p)) \\
& -0.04068 \cos (2 \log (\Delta p)) \\
& -0.2271 \sin (2 \log (\Delta p)))
\end{aligned}
$$




$$
\begin{aligned}
J_{o, \text { rear }\left[\frac{\mathrm{A}}{\mathrm{cm}^{2}}\right]=} & \left(\frac{8.27}{8.52}\right)^{2} \\
& \cdot 10^{\wedge}(1.029+0.293 \cos (1.304 \log (\Delta p) \\
& -0.5323 \sin (1.304 \log (\Delta p)) \\
& +0.01279 \cos (2.608 \log (\Delta p)) \\
& +0.1621 \sin (2.608 \log (\Delta p))) .
\end{aligned}
$$

\section{B. Rear $S_{\mathrm{eff}}$ of the PERL (UNSW) Cell}

The best fit to the data in [Fig. 6, 76] was achieved by the following double exponential function, where $\Delta n\left[\mathrm{~cm}^{-3}\right]$ denotes the excess carrier density at the boundary:

$$
\begin{aligned}
S_{\text {eff }}\left[\frac{\mathrm{cm}}{\mathrm{s}}\right]= & 10^{\wedge}\left(3.262 \times 10^{14}\right. \\
& \exp \left(-\left(\frac{\log (\Delta n)+395.3}{71.14}\right)^{2}\right) \\
& \left.+1.35 \exp \left(-\left(\frac{\log (\Delta n)-10.88}{2.229}\right)^{2}\right)\right) .
\end{aligned}
$$

\section{REFERENCES}

[1] A. Fell et al., "Input parameters for the simulation of silicon solar cells in 2014," presented at the 6th World Conf. Photovoltaic Energy Convers., Kyoto, Japan, 2014.

[2] (2015). PV Lighthouse Solar Cell Library. [Online]. Available: http://pvlighthouse.com.au/resources/solar\%20cell\%20library/solar\%20 cell\%20library.aspx

[3] Synopsys, Sentaurus: Sentaurus Device User Guide, Release H-2013.03, 2013.

[4] (2015). PV Lighthouse. [Online]. Available: http://pvlighthouse.com.au

[5] S. C. Baker-Finch and K. R. McIntosh, "One-dimensional photogeneration profiles in silicon solar cells with pyramidal texture," Progr. Photovoltaics: Res. Appl., vol. 20, pp. 51-61, 2012.

[6] A. Fell and K. R. McIntosh, "Deriving the generation profile for silicon solar cells from lumped optical parameters," presented at the 42rd IEEE Photovoltaic Spec. Conf., New Orleans, LA, USA, 2015.

[7] P. A. Basore, "Numerical modeling of textured silicon solar cells using PC-1D," IEEE Trans. Electron Devices, vol. 37, no. 2, pp. 337-343, Feb. 1990.

[8] A. Fell, "A free and fast three-dimensional/two-dimensional solar cell simulator featuring conductive boundary and quasi-neutrality approximations," IEEE Trans. Electron Devices, vol. 60, no. 2, pp. 733-738, Feb. 2013.

[9] A. Goetzberger, J. Knobloch, B. Voss, and R. Waddington, Crystalline Silicon Solar Cells. Chichester, U.K.: Wiley, 1998.

[10] A. Fell, K. C. Fong, K. R. McIntosh, E. Franklin, and A. W. Blakers, "3-D simulation of interdigitated-back-contact silicon solar cells with quokka including perimeter losses," IEEE J. Photovoltaics, vol. 4, no. 4, pp. 1040 1045, Jul. 2014.

[11] R. Brendel, "Modeling solar cells with the dopant-diffused layers treated as conductive boundaries," Progr. Photovoltaics: Res. Appl., vol. 20, pp. 31-43, 2012

[12] P. A. Basore and K. Cabanas-Holmen, "PC2D: A circular-reference spreadsheet solar cell device simulator," IEEE J. Photovoltaics, vol. 1, no. 1, pp. 72-77, Jul. 2011.

[13] A. Cuevas and R. A. Sinton, "Detailed modelling of silicon solar cells," in Proc. 23rd Eur. Photovoltaic Sol. Energy Conf., Valencia, Spain, 2008, pp. 315-319.

[14] A. Cuevas, "Physical model of back line-contact front-junction solar cells," J. Appl. Phys., vol. 113, p. 164502, 2013.

[15] (2014). Atlas Device Simulator, Silvaco Int. Softw., Santa Clara, CA, USA.
[16] K. R. McIntosh and P. P. Altermatt, "A freeware 1D emitter model for silicon solar cells," in Proc. 35th IEEE Photovoltaic Spec. Conf., 2010, pp. 002188-002193.

[17] M. Padilla et al., "Surface recombination parameters of interdigitatedback-contact silicon solar cells obtained by modeling luminescence images," Sol. Energy Mater. Sol. Cells, vol. 120, Part A, pp. 363-375, 2014.

[18] K. Rapolu, P. Singh, and S. Shea, "Two dimensional numerical modeling of a silicon solar cell with selective emitter configuration," in Proc. 35th IEEE Photovoltaic Spec. Conf., 2010, pp. 002227-002232.

[19] D. A. Clugston and P. A. Basore, "PC1D version 5: 32-bit solar cell modeling on personal computers," in Proc. 26th IEEE Photovoltaic Spec. Conf., 1997, pp. 207-210.

[20] H. Haug, A. Kimmerle, J. Greulich, A. Wolf, and E. Stensrud Marstein, "Implementation of Fermi-Dirac statistics and advanced models in PC1D for precise simulations of silicon solar cells," Sol. Energy Mater. Sol. Cells, vol. 131, pp. 30-36, Dec. 2014.

[21] P. P. Altermatt, "Models for numerical device simulations of crystalline silicon solar cells-A review," J. Comput. Electron., vol. 10, pp. 314-330, Sep. 2011.

[22] D. E. Kane and R. M. Swanson, "Measurement of the emitter saturation current by a contactless photoconductivity decay method," in Proc. 18th IEEE Photovoltaic Spec. Conf., 1985, pp. 578-583.

[23] K. Misiakos and D. Tsamakis, "Accurate measurements of the silicon intrinsic carrier density from 78 to $340 \mathrm{~K}$," J. Appl. Phys., vol. 74, pp. 3293-3297, 1993.

[24] P. P. Altermatt, A. Schenk, F. Geelhaar, and G. Heiser, "Reassessment of the intrinsic carrier density in crystalline silicon in view of band-gap narrowing," J. Appl. Phys., vol. 93, pp. 1598-1604, 2003.

[25] A. Schenk, "Finite-temperature full random-phase approximation model of band gap narrowing for silicon device simulation," J. Appl. Phys., vol. 84, pp. 3684-3695, 1998.

[26] A. Richter, S. W. Glunz, F. Werner, J. Schmidt, and A. Cuevas, "Improved quantitative description of Auger recombination in crystalline silicon," Phys. Rev. B, vol. 86, p. 165202, 2012.

[27] T. Trupke et al., "Temperature dependence of the radiative recombination coefficient of intrinsic crystalline silicon," J. Appl. Phys., vol. 94, pp. 4930-4937, 2003.

[28] D. B. M. Klaassen, "A unified mobility model for device simulation-I. Model equations and concentration dependence," Solid-State Electron., vol. 35, pp. 953-959, 1992.

[29] C. Gueymard, SMARTS2: A Simple Model of the Atmospheric Radiative Transfer of Sunshine: Algorithms and Performance Assessment, Cocoa, FL, USA: Florida Solar Energy Cent., 1995.

[30] M. A. Green, "Self-consistent optical parameters of intrinsic silicon at 300K including temperature coefficients," Sol. Energy Mater. Sol. Cells, vol. 92, pp. 1305-1310, 2008.

[31] S. P. Group, International Technology Roadmap for Photovoltaic, Mar. 2014.

[32] M. Abbott, G. Scardera, K. R. McIntosh, and A. Meisel, "Simulation of emitter doping profiles formed by industrial POCl3 processes," in Proc. IEEE 39th Photovoltaic Spec. Conf., 2013, pp. 1383-1388.

[33] Y. Li, Z. Li, Y. Zhao, and A. Lennon, "Modelling of light trapping in acidic-textured multicrystalline silicon wafers," Int. J. Photoenergy, vol. 2012, p. 369101, 2012.

[34] S. C. Baker-Finch, K. R. McIntosh, and M. L. Terry, "Isotextured silicon solar cell analysis and modeling 1: Optics," IEEE J. Photovoltaics, vol. 2, no. 4, pp. 457-464, Oct. 2012.

[35] J. Greulich et al., "Optical simulation and analysis of iso-textured silicon solar cells including light trapping," presented at the 5th Int. Conf. Crystalline Silicon Photovoltaics, Constance, Germany, 2015.

[36] B. T. Phong, "Illumination for computer generated pictures," Commun. ACM, vol. 18, pp. 311-317, 1975.

[37] M. Abbott et al., "Silicon ink selective emitter solar cells on multicrystalline silicon wafers," presented at the 25th Photovoltaic Sol. Energy Conf. Exhib. Conf., Valencia, Spain, 2010.

[38] A. Dastgheib-Shirazi, M. Steyer, G. Micard, H. Wagner, P. P. Altermatt, and G. Hahn, "Relationships between diffusion parameters and phosphorus precipitation during the $\mathrm{POCl}_{3}$ diffusion process," Energy Procedia, vol. 38, pp. 254-262, 2013.

[39] B. Min, H. Wagner, A. Dastgheib Shirazi, A. Kimmerle, H. Kurz, and P. P. Altermatt, "Heavily doped Si: P emitters of crystalline Si solar cells: recombination due to phosphorus precipitation," Phys. Status Solidi (RRL)—Rapid Res. Lett., vol. 8, pp. 680-684, 2014. 
[40] R. Bock, P. P. Altermatt, J. Schmidt, and R. Brendel, "Formation of aluminum-oxygen complexes in highly aluminum-doped silicon," Semicond. Sci. Technol., vol. 25, p. 105007, 2010.

[41] M. Rüdiger, M. Rauer, C. Schmiga, and M. Hermle, "Effect of incomplete ionization for the description of highly aluminum-doped silicon," J. Appl. phys., vol. 110, p. 024508, 2011.

[42] P. Rosenits, T. Roth, and S. W. Glunz, "Erratum on "Determining the defect parameters of the deep aluminum-related defect center in silicon [Appl. Phys. Lett. 91, 122109 (2007)]," Appl. Phys. Lett., vol. 99, p. 239904, 2011.

[43] S. Duttagupta, F. Ma, B. Hoex, T. Mueller, and A. G. Aberle, "Optimised antireflection coatings using silicon nitride on textured silicon surfaces based on measurements and multidimensional modelling," Energy Procedia, vol. 15, pp. 78-83, 2012.

[44] R. Woehl, M. Hörteis, and S. Glunz, "Determination of the effective optical width of screen printed and aerosol printed and plated fingers," in Proc. 23rd Eur. Photovoltaic Sol. Energy Conf. Exhib., 2008, pp. 1377-1382.

[45] M. Rüdiger, C. Schmiga, M. Rauer, M. Hermle, and S. W. Glunz, "Efficiency potential of n-type silicon solar cells with aluminum-doped rear p+ emitter," IEEE Trans. Electron Devices, vol. 59, no. 5, pp. 1295-1303, May 2012.

[46] M. Rüdiger, C. Schmiga, M. Rauer, M. Hermle, and S. W. Glunz, "Optimisation of industrial n-type silicon solar cells with aluminium-alloyed rear emitter by means of 2D numerical simulation," in Proc. 25th Eur. Photovoltaic Sol. Energy Conf. Exhib., Valencia, Spain, 2010, pp. 2280 2286.

[47] J. Schmidt et al., "Impurity-related limitations of next-generation industrial silicon solar cells," in Proc. IEEE 38th Photovoltaic Spec. Conf., 2012, pp. 1-5.

[48] J. Greulich, N. Wöhrle, M. Glatthaar, and S. Rein, "Optical modeling of the rear surface roughness of passivated silicon solar cells," Energy Procedia, vol. 27, pp. 234-239, 2012.

[49] N. Wohrle, J. Greulich, C. Schwab, M. Glatthaar, and S. Rein, "A predictive optical simulation model for the rear-surface roughness of passivated silicon solar cells," IEEE J. Photovoltaics, vol. 3, no. 1, pp. 175-182, Jan. 2013

[50] S. C. Baker-Finch, K. R. McIntosh, M. L. Terry, and Y. Wan, "Isotextured silicon solar cell analysis and modeling 2: Recombination and device modeling," IEEE J. Photovoltaics, vol. 2, no. 4, pp. 465-472, Oct. 2012.

[51] P. Saint-Cast, D. Kania, M. Hofmann, J. Benick, J. Rentsch, and R. Preu, "Very low surface recombination velocity on p-type c-Si by high-rate plasma-deposited aluminum oxide," Appl. Phys. Lett., vol. 95, pp. 151502$1-151502-3,2009$.

[52] L. E. Black and K. R. McIntosh, "Modeling recombination at the $\mathrm{Si}-\mathrm{AlO}$ interface," IEEE J. Photovoltaics, vol. 3, no. 3, pp. 936-943, Jul. 2013.

[53] I. Romijn, A. Gutjahr, D. Saynova, J. Anker, E. Kossen, and K. Tool, "Cost effective n-Pasha solar cells with efficiency above 20\%," Photovoltaics Int., vol. 20, pp. 33-40, 2013.

[54] A. Burgers et al., "19.5\% efficient n-type $\mathrm{Si}$ solar cells made in production," in Proc. 26th Eur. Photovoltaic Sol. Energy Conf., 2011, pp. $1144-1147$

[55] G. J. M. Janssen, A. Gutjahr, A. R. Burgers, D. S. Saynova, I. Cesar, and I. G. Romijn, "Power loss analysis of n-PASHA cells validated by 2D simulations," in Proc. 28th Eur. Photovoltaic Sol. Energy Conf. Exhib., Paris, France, 2013, pp. 1548-1553.

[56] K. Masuko et al., "Achievement of more than 25\% conversion efficiency with crystalline silicon heterojunction solar cell," IEEE J. Photovoltaics, vol. 4, no. 6, pp. 1433-1435, Nov. 2014.

[57] M. A. Green, K. Emery, Y. Hishikawa, W. Warta, and E. D. Dunlop, "Solar cell efficiency tables (version 42)," Progr. Photovoltaics: Res. Appl., vol. 21 , pp. 827-837, 2013.

[58] L. Zhepeng, "Design, fabrication and characterisation of thin-film materials for heterojunction silicon wafer solar cells," Ph.D. dissertation, Dept. Elect. Comput. Eng., Univ. Singapore, Singapore, 2014.

[59] A. Khanna, Z. P. Ling, V. Shanmugam, M. B. Boreland, I. Hayashi, D. Kirk et al., "Screen printed metallisation for silicon heterojunction solar cells," in Proc. 28th Eur. Photovoltaic Sol. Energy Conf. Exhib., Paris, France, 2013, pp. 1336-1339.

[60] Z. C. Holman, A. Descoeudres, L. Barraud, F. Z. Fernandez, J. P. Seif, S. De Wolf et al., "Current losses at the front of silicon heterojunction solar cells," IEEE J. Photovoltaics, vol. 2, no. 1, pp. 7-15, Jan. 2012.
[61] Z. C. Holman, M. Filipič, A. Descoeudres, S. De Wolf, F. Smole, M. Topič et al., "Infrared light management in high-efficiency silicon heterojunction and rear-passivated solar cells," J. Appl. Phys., vol. 113, p. 013107, 2013

[62] J. Geissbuhler, S. De Wolf, A. Faes, N. Badel, Q. Jeangros, A. Tomasi et al., "Silicon heterojunction solar cells with copper-plated grid electrodes: Status and comparison with silver thick-film techniques," IEEE J. Photovoltaics, vol. 4, no. 4, pp. 1055-1062, Jul. 2014.

[63] M. Rahmouni, A. Datta, P. Chatterjee, J. Damon-Lacoste, C. Ballif, and P. R. I Cabarrocas, "Carrier transport and sensitivity issues in heterojunction with intrinsic thin layer solar cells on N-type crystalline silicon: A computer simulation study," J. Appl. Phys., vol. 107, p. 054521, 2010.

[64] M. Taguchi, E. Maruyama, and M. Tanaka, "Temperature dependence of amorphous/crystalline silicon heterojunction solar cells," Jpn. J. Appl. Phys., vol. 47, p. 814, 2008.

[65] J. Zhao, A. Wang, M. A. Green, and F. Ferrazza, "19.8\% efficient "honeycomb" textured multicrystalline and $24.4 \%$ monocrystalline silicon solar cells," Appl. Phys. Lett., vol. 73, pp. 1991-1993, 1998.

[66] J. Zhao, A. Wang, and M. A. Green, "24 · 5\% efficiency silicon PERT cells on MCz substrates and 24.7\% efficiency PERL cells on FZ substrates," Progr. Photovoltaics: Res. Appl., vol. 7, pp. 471-474, 1999.

[67] A. G. Aberle, P. P. Altermatt, G. Heiser, S. J. Robinson, A. Wang, J. Zhao, et al., "Limiting loss mechanisms in $23 \%$ efficient silicon solar cells," $J$. Appl. Phys., vol. 77, pp. 3491-3504, 1995.

[68] P. P. Altermatt, G. Heiser, A. G. Aberle, A. Wang, J. Zhao, S. J. Robinson, et al., "Spatially resolved analysis and minimization of resistive losses in high-efficiency Si solar cells," Progr. Photovoltaics: Res. Appl., vol. 4, pp. 399-414, 1996.

[69] J. Zhao and M. A. Green, "Optimized antireflection coatings for highefficiency silicon solar cells," IEEE Trans. Electron Devices, vol. 38, no. 8, pp. 1925-1934, Aug. 1991.

[70] P. P. Altermatt, G. Heiser, and M. A. Green, "Numerical quantification and minimization of perimeter losses in high-efficiency silicon solar cells," Progr. Photovoltaics: Res. Appl., vol. 4, pp. 355-367, 1996.

[71] M. J. Dodge, "Refractive properties of magnesium fluoride," Appl. Opt., vol. 23, pp. 1980-1985, 1984.

[72] E. D. Palik, Ed., Handbook of Optical Constants of Solids (Academic Press Handbook Series), vol. 1. New York, NY, USA: Academic, 1985.

[73] P. Campbell and M. A. Green, "Light trapping properties of pyramidally textured surfaces," J. Appl. Phys., vol. 62, pp. 243-249, 1987.

[74] A. Blakers, "Shading losses of solar-cell metal grids," J. Appl. Phys. vol. 71, pp. 5237-5241, 1992.

[75] P. P. Altermatt, J. O. Schumacher, A. Cuevas, M. J. Kerr, S. W. Glunz, R. R. King, et al., "Numerical modeling of highly doped Si:P emitters based on Fermi-Dirac statistics and self-consistent material parameters," J. Appl. Phys., vol. 92, pp. 3187-3197, 2002.

[76] S. J. Robinson, S. R. Wenham, P. P. Altermatt, A. G. Aberle, G. Heiser and M. A. Green, "Recombination rate saturation mechanisms at oxidized surfaces of high-efficiency silicon solar cells," J. Appl. Phys., vol. 78, pp. 4740-4754, 1995.

[77] E. Franklin, et al., "Design, fabrication and characterisation of a $24.4 \%$ efficient interdigitated back contact solar cell," Progr. Photovoltaics: Res. Appl., 2014. doi: 10.1002/pip.2556

[78] D. D. Smith, P. Cousins, S. Westerberg, R. D. Jesus-Tabajonda, G. Aniero, and Y. Shen, "Toward the practical limits of silicon solar cells," IEEE J. Photovoltaics, vol. 4, no. 6, pp. 1465-1469, Nov. 2014.

[79] K. C. Fong, K. Teng, K. R. McIntosh, A. W. Blakers, E. Franklin, $\mathrm{N}$. Zin, et al., "N+ diffusion and contact optimisation of IBC solar cells," presented at the 28th Eur. PV Sol. Energy Conf., Paris, France, 2013.

[80] K. R. McIntosh et al., "Quantifying the optical losses in back-contact solar cells," in Proc. IEEE 40th Photovoltaic Spec. Conf., 2014, pp. 0115-0123.

[81] K. R. McIntosh and L. E. Black, "On effective surface recombination parameters," J. Appl. Phys., vol. 116, pp. 014503, 2014.

Authors' photographs and biographies not available at the time of publication. 